\title{
Safeguards and the perils of preferential trade agreements: Dominican Republic-Safeguard Measures
}

\author{
CHAD P. BOWN* \\ The World Bank and CEPR \\ MARK WU* * \\ Harvard Law School
}

\begin{abstract}
The legal-economic implications of how WTO members apply an import-restricting safeguard measure become more complex in light of the increasing web of trade concessions undertaken through their preferential trade agreements (PTAs) in addition to their WTO commitments. This paper examines a number of complex issues that arose in the WTO litigation between five new PTA partners through the Dominican Republic-Safeguard Measures disputes. First, we highlight the difficulties in assessing the extent to which safeguards imposed following a PTA are the result of PTA concessions relative to developments that pre-date or are otherwise unrelated to the PTA. Second, we examine how the WTO Panel resolved a number of previously unanswered questions in the WTO's safeguards jurisprudence that arose in these cases. We suggest that the Panel rightly foreclosed a number of potentially dubious practices that WTO members might otherwise have pursued when using safeguards to circumvent trade concessions. Third, we identify how safeguardrelated provisions within a PTA may give rise to constraints that subsequently affect how a country may apply safeguards available under the WTO Agreements, and we describe some implications for PTA design and negotiation. Finally, we analyze the broader implications that arise from the interplay of PTAs, safeguards, and dispute settlement in light of the availability of both relatively substitutable policy instruments and dispute resolution forums.
\end{abstract}

\footnotetext{
*Email: cbown@worldbank.org.

**Email: mwu@law.harvard.edu.

Thanks to Jasper Wauters, Niall Meagher, Petros Mavroidis, Bernard Hoekman, and other participants at the WTO Case Law workshop at the European University Institute on 3 June 2013 for helpful comments. Aksel Erbahar and Carys Golesworthy provided outstanding research assistance. Bown acknowledges research funding through the World Bank's MDTF-II Trust Fund. Any opinions expressed in this paper are the authors' own and should not be attributed to the World Bank or any government. Although Wu served as a negotiator on the preferential trade agreement discussed in this paper, all of the information discussed within is based on publicly available sources that do not touch upon the provisions which he personally negotiated. All remaining errors are our own.
} 


\section{Introduction}

As the Doha Round of multilateral trade negotiations stalled, subsets of WTO members negotiated a number of preferential trade agreements (PTAs) with each other. Unlike the multilateral agreements which require that tariff and market access concessions on goods and services be extended to all WTO members, a PTA allows WTO members to limit concessions to its PTA partners only. This ensures that each party to a PTA gains preferential access to the other's market - i.e., better tariffs and/or market access terms than those accorded to other WTO members with whom a PTA has not been concluded. Such agreements are undertaken voluntarily; governments entering into PTAs expect the mutual elimination of tariffs to lead to higher aggregate welfare in all participating countries.

While a country may experience an overall welfare gain from a PTA, as in multilateral liberalization efforts, there are likely to be both winners and losers among its domestic industries. What happens, however, when the welfare loss resulting from a surge in imports for a given industry is much greatereconomically and/or politically-than policy-makers anticipated? In general, WTO rules set forth a procedure whereby a country may impose a safeguard on a particular product, allowing the government to legally suspend its negotiated WTO concessions for a fixed period of time. The safeguard mechanism functions as an escape clause, granting countries a limited reprieve to take additional policy measures to address the adjustment needs of the affected domestic industry. ${ }^{1}$ However, environments that intertwine safeguard use, PTA commitments, and WTO commitments introduce substantial additional complexities.

This article examines how the WTO's Dominican Republic-Safeguard Measures disputes raise a new set of issues concerning the intersection of PTAs and safeguards. The cases filed by four Central American countries - Costa Rica (DS 415), Guatemala (DS 416), Honduras (DS 417), and El Salvador (DS 418)-are unique in two ways. First, the disputes represent one of the relatively few times that a country has used WTO dispute settlement to challenge one of its PTA trading partners over the use of safeguards against its imports. ${ }^{2}$ Second, these disputes

1 The economic argument that safeguards operate as an escape clause for countries facing adverse economic shocks following concessions made in a trade agreement has been elaborated upon by several scholars, including Bagwell and Staiger (1990) and Fischer and Prusa (2003). Crowley (2010) finds some empirical support in a cross-country analysis for the proposition that the inclusion of safeguards facilitates greater tariff reductions. Bown and Crowley (2013a) provide industry-level evidence for the United States that both safeguards and antidumping use can be interpreted as responding to the sorts of economic shocks posited by the Bagwell and Staiger (1990) theory.

2 An earlier case concerning safeguards was brought by Norway against the EU member states, which are all parties to the European Free Trade Association (EFTA). See Request for Consultations by Norway, European Communities-Definitive Safeguard Measures on Salmon, WT/DS328/1, 3 March 2005. A related case was also brought by Chile, which had concluded a PTA (EU-Chile Association Agreement) with the EU prior to the dispute. See Request for Consultations by Chile, European Communities - Definitive Safeguard Measures on Salmon, WT/DS326/1, 8 February 2005. 
represent the first time that the WTO has examined the question of whether a policy measure constitutes an illegal safeguard, even though the applied tariff rate does not exceed the bound tariff rate in the WTO member's Schedule (and by extension, its commitments on quotas and other quantitative restrictions). While it is uncommon for a legal case to materialize under such circumstances, we argue that the interplay between the Dominican Republic's multilateral and PTA commitments likely contributed to the applied safeguard and that the WTO Panel was correct to declare it to be problematic.

WTO law establishes fairly stringent terms for when a safeguard may be invoked so as to ensure that WTO members do not abuse this escape clause mechanism. The General Agreement on Tariffs and Trade (GATT) Article XIX permits a WTO member to use a safeguard only in situations where 'as a result of unforeseen developments and the effect of the obligations incurred by a contracting party under this Agreement, [a] product... is being imported into the territory of a contracting party in such increased quantities and under such conditions as to threaten serious injury to domestic producers in that territory of like or directly competitive products.' During the Uruguay Round, countries decided that further legal clarification was necessary. They concluded an additional treaty-the Agreement on Safeguards - which elaborates further the legal requirements for invoking a safeguard. As a result, WTO members must now comply with a set of procedural requirements when conducting an investigation on whether to impose safeguards, and they must adhere to various substantive requirements concerning potential compensation, exceptions for developing countries, etc.

To ensure that safeguards do not lead to discrimination among countries in the multilateral regime, WTO law requires that a policy measure (e.g., increased tariffs) undertaken as part of a safeguard be applied to all WTO members. This most common form of a safeguard is sometimes referred to as a 'WTO global safeguard'. However, in 2001, the WTO introduced the concept of a 'countryspecific safeguard'. As part of its accession to the WTO, China agreed to allow WTO members to impose a transitional safeguard against only China's exports in circumstances where its products cause a 'market disruption' to the domestic producer of a like or directly competitive product. ${ }^{3}$

Originally, the concept of a safeguard was designed to provide countries with a temporary reprieve from the trade concessions that they had made at the multilateral level. But as PTAs have become more prevalent, safeguards have also found their way into bilateral and plurilateral PTAs. Today, a WTO member that is a party to a PTA remains subject to the safeguard obligations stipulated at the multilateral level in GATT Article XIX and the Agreement on Safeguards. But it is

3 Protocol on the Accession of the People's Republic of China, WT/L/432, adopted 23 November 2001, para. 16.1 . 
also obliged to follow any further treaty commitments concerning safeguards that it made within its PTAs.

Like other provisions in PTAs, the additional PTA rules concerning safeguards may be 'WTO-plus' (WTO+), meaning they are more stringent than those required by the WTO, or 'WTO-extra' (WTO-X), meaning they cover additional scope beyond those of the WTO. In other words, the legal commitments set forth in the PTAs may extend beyond those of GATT Article XIX and the Agreement on Safeguards, so long as they do not contravene the multilateral obligations. ${ }^{4}$ Moreover, many PTAs permit a party to impose a 'PTA-specific safeguard'. ${ }^{5}$ Just as is the case in the multilateral regime, a PTA-specific safeguard provides an escape mechanism for countries seeking temporary reprieve from trade concessions made in a PTA.

With this myriad of multilateral, bilateral, and plurilateral rules, there is the invariable possibility of tension. However, the main legal issue arising thus far from the intersection of PTAs and safeguards was whether a WTO member is allowed to exempt a PTA partner from an applied safeguard measure. Several cases, beginning with Argentina-Safeguards, have tackled this question. The Appellate Body (AB) made clear that a WTO member must follow the parallelism principle in deciding whether to include or exclude imports from a PTA partner in or from the safeguards. ${ }^{6}$ That is to say, if it wished to impose safeguards against imports from a PTA partner, it must include those imports in the analysis assessing whether its domestic industry was seriously injured on account of the increase in imports. And if it wished to exclude imports from PTA members from the safeguards, then similarly, it must exclude those imports when performing its injury analysis. The soundness of the parallelism principle has been forcefully criticized by several scholars; nevertheless, it remains established law. ${ }^{7}$ Consequently, a number of WTO members have recently applied safeguard measures against

4 For additional details about the types of WTO + and WTO-X obligations concerning safeguards found in PTAs, see Teh et al. (2009: 207-238) and Prusa (2011). Both reports analyse provisions in a representative sample of 74 PTAs. Note that even the mere inclusion of a trade remedy notification requirement to a 'joint committee' of the PTA parties may have a de facto chilling effect on the application of safeguards between PTA partners (Baldwin et al., 2009: 121-123).

5 Of a representative sample of 74 PTAs analysed by Teh et al. (2009) and Prusa (2011), 69 allow for the imposition of PTA-specific safeguards, but 65 specify additional WTO + or WTO-X rules concerning its application.

6 See Appellate Body Report, Argentina-Safeguard Measures on Imports of Footwear, WT/DS121/ AB/R, adopted 12 January 2000, paras. 112-114 (hereinafter Argentina-Footwear (EC)); Appellate Body Report, United States-Definitive Safeguard Measures on Imports of Wheat Gluten from the European Communities, WT/DS66/AB/R, adopted 19 January 2001, paras. 95-96 (hereinafter US-Wheat Gluten); Appellate Body Report, United States-Definitive Safeguard Measures on Imports of Circular Welded Carbon Quality Line Pipe from Korea, WT/DS202/AB/R, adopted 8 March 2002, paras. 178-181 and 187 (hereinafter US-Line Pipe).

7 For example, Pauwelyn (2004) criticizes the Appellate Body for introducing an unnecessary complication with no clear textual basis for supporting the creation of this doctrine. Ahn (2006) argues that the Appellate Body was not the proper forum for deciding this question and creates a serious loophole for the MFN application of a safeguard. Bown and McCulloch $(2003,2004)$ examine the empirical impact 
PTA members - for example, Turkey has included the European Union among the targeted exporters in a number of its recently applied safeguards, despite its customs union obligations. ${ }^{8}$

This paper makes three main arguments concerning the Dominican RepublicSafeguard Measures disputes. First, a common narrative that arises when a safeguard or other trade remedy is applied subsequent to the implementation of a trade agreement is that the agreement itself is responsible for the subsequent economic shocks that trigger the policy activation. ${ }^{9}$ In Section 2, we suggest that as far as the Dominican Republic-Safeguard Measures cases are concerned, the actual chain of events is likely to be more complex. We illustrate how these particular disputes were not triggered singlehandedly by trade concessions made in the PTA, but instead likely result from a series of developments, some of which pre-date the existing PTA. This underscores the importance of analysing a longer time horizon with respect to both economic and legal developments, in seeking to understand the underlying causes of a WTO dispute involving both safeguards and PTAs.

Second, these disputes give rise to a new set of issues under WTO law concerning the intersection of safeguards and PTAs. In Section 3, we review the Panel's adjudication of four novel legal issues in Dominican Republic-Safeguard Measures. Our detailed examination of each issue allows us to conclude that the Panel has rightly foreclosed a number of potentially dubious practices that WTO members might otherwise have pursued when enacting safeguards to circumvent their trade concessions.

Third, we argue that the interplay between PTAs, safeguards, and WTO litigation is more complex than simply the impact that a PTA has through the lowering of tariffs and other trade barriers. In particular, PTAs may impose additional constraints on a country's ability to exercise policy options to respond to increased foreign competition through escape clause mechanisms. These PTAimposed constraints, in turn, may lead a government to take actions that are inconsistent with the country's overall WTO commitments. Section 4 explores how this dynamic transpired in the Dominican Republic-Safeguard Measures cases.

Finally, our aim is to use these disputes to raise additional concerns regarding the perils of PTAs. These extend beyond the reciprocal opening of one's own market to additional foreign competition. They also include the additional legal constraints

of this, as well as other exceptions to the general principle of MFN non-discrimination in how countries applied safeguards over the initial WTO period of 1995-2000.

8 For an analysis of Turkey's contingent protection measures, see Bown (2014).

9 Finger and Nogués (2006) discuss the experience of various Latin American countries with respect to safeguards and antidumping, and Bown and Tovar (2011) analyse the experience of India which has emerged as the leading user of safeguards and antidumping in the WTO era. This narrative is also being applied to the current controversy over Ukraine's safeguards for its domestic auto industry. Auyezov (2013) notes that Ukraine's car output had fallen $79 \%$ since it enacted tariff cuts following its WTO accession, thereby triggering the application of safeguards. 
Figure 1. Dominican Republic macroeconomic indicators, 2000-2011

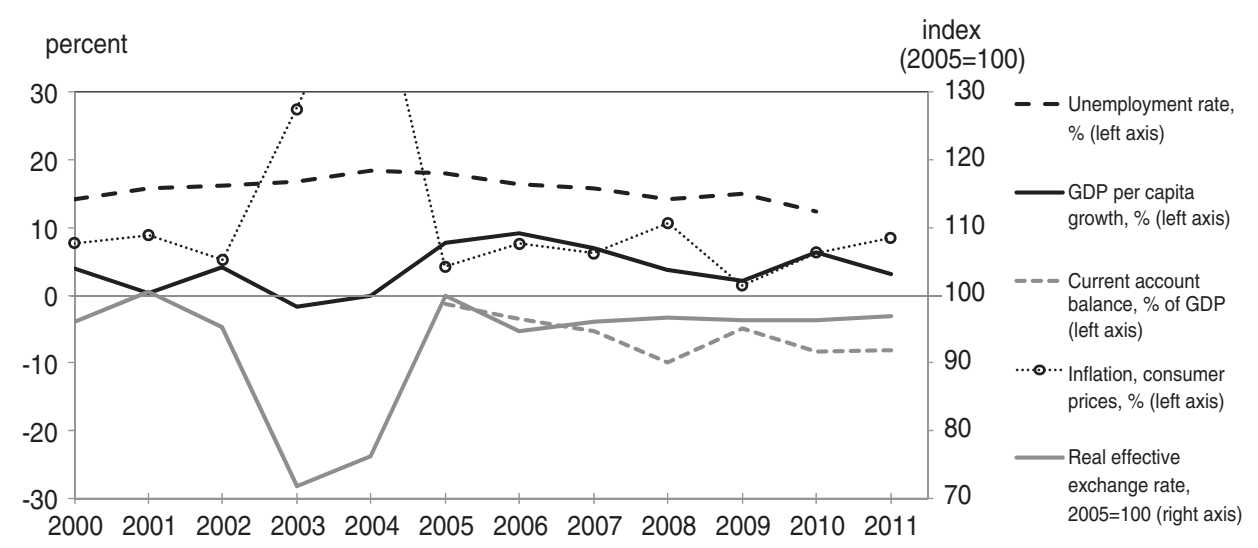

Source: Compiled by the authors with data from World Bank's World Development Indicators.

Dominican Republic's inflation reached 51.5\% (not shown for scaling purposes) in 2004. Current account data not available before 2005, unemployment rate data not available for 2011.

that a PTA may place on a country's ability to exercise policy options to assist domestic industry in adjusting to trade shocks.

\section{Economic and legal background}

This section establishes the background set of economic and legal facts surrounding the Dominican Republic-Safeguard Measures disputes.

\subsection{Setting the stage: CAFTA-DR and the Dominican Republic's macroeconomic climate}

The Dominican Republic is a small, island economy in the Caribbean. In 2010, it had a population of 10 million people and a GDP per capita of $\$ 5,195$, which put it into the World Bank's category of upper middle income economies.

Figure 1 presents information from 2000-2011 for a number of standard macroeconomic indicators so as to provide context for the general economic climate facing the Dominican Republic. The most striking feature of the data is the Dominican Republic's economic and financial crisis in 2003-2004 during which real GDP growth and real per capita GDP growth turned negative and the unemployment rate increased to a high of $18.4 \%$ of the labour force. Inflation spiked, and the real exchange rate depreciated sharply.

In the period since 2005, however, macroeconomic conditions in the Dominican Republic have improved considerably. Between 2005 and 2011, GDP growth has averaged $7.0 \%$ per year, GDP per capita growth has averaged $5.6 \%$ per year, and annual inflation rates have averaged only 6.4\%. By 2010, the unemployment rate had fallen to $12.4 \%$. Even at the height of the global Great Recession in 
2008-2009, as unemployment spiked, GDP plummeted, and trade collapsed across both advanced and emerging markets, the economic impact on the Dominican Republic was relatively minor and short-lived. ${ }^{10}$

While the overall macroeconomic conditions since 2005 have been positive, one potential sign of concern is the Dominican Republic's significant and widening current account surplus - with imports growing faster than exports. Between 2007 and 2011, the current account surplus fluctuated between 5\% and 10\% of GDP. There was a brief respite in 2009, as imports and exports for most all countries around the world shrank that year alongside the global trade collapse, and the current account surplus has since stabilized at around $8 \%$ of GDP by 2011 . The trade deficit grew alongside what was essentially a flat real exchange rate during 2005-2011 and otherwise stable macroeconomic conditions, especially in light of the economic turmoil taking place elsewhere around the globe during the Great Recession.

The Dominican Republic has had a fairly active trade policy since the late 1990s, which has likely contributed to its growing trade volume, as its government pursued a strategy of negotiating PTAs with its regional trading partners. In February 1998, the Dominican Republic launched PTA negotiations with five Central American countries (Costa Rica, El Salvador, Guatemala, Honduras, and Nicaragua). The parties signed the Central America-Dominican Republic Free Trade Agreement (CA-DR FTA) in November 1998, but then encountered delays in the ratification process. It took until March 2001 for the Dominican Republic's Senate to approve the treaty, which then entered into force on 3 October 2001.

In the midst of the Dominican Republic's economic and financial crisis in 2003-2004, the five Central American countries with which the Dominican Republic had concluded the CA-DR FTA began negotiations for a separate PTA with the United States, known as the Central America Free Trade Agreement (CAFTA). The Dominican Republic also subsequently sought to join its Central American PTA partners in obtaining preferential access to the much-valued American market, and in November 2003, the United States agreed to talks aimed at integrating the Dominican Republic into the CAFTA negotiations.

However, before the Dominican Republic could enter formally into the negotiations, the US and four of the five Central American countries successfully concluded the CAFTA negotiations in December 2003. ${ }^{11}$ Thus, when formal talks with Dominican negotiators commenced in January 2004, the negotiations were

10 Bown (2011), for example, documents the impact on real GDP growth, imports, and increases to temporary trade barriers (TTBs) such as antidumping, safeguards, and countervailing duties for the major G20 economies during this period.

11 The exception was Costa Rica, which did not manage to reach agreement with the US in December 2003 because of a series of outstanding issues for which Costa Rica, unlike the other four Central American countries, was unwilling to accept. However, on 25 January 2004, the US and Costa Rica managed successfully to reach agreement over these outstanding issues. 
Table 1. Timeline/dates of interest

\section{Event}

5 August 2004

2006

1 March 2007

15 September 2008

1 January 2009

20 July 2009

15 December 2009

16 March 2010

10 October 2010

15 October 2010
United States, Costa Rica, El Salvador, Guatemala, Honduras, Nicaragua, and the Dominican Republic sign the Dominican Republic-Central America-United States Free Trade Agreement (CAFTA-DR)

CAFTA-DR enters into force for United States, El Salvador, Guatemala, Honduras, and Nicaragua

CAFTA-DR enters into force for Dominican Republic

Lehman Brothers investment bank files for bankruptcy in United States

(Great Recession, Trade Collapse of 2008/9)

CAFTA-DR enters into force for Costa Rica

Fertilizantes Santo Domingo C. por A. (FERSAN) requests Dominican Republic's

Tariff Studies Commission to initiate a safeguard investigation on imports of polypropylene bags (6305.33.10 and 6305.33.90) and tubular fabric (5407.20.20)

Dominican Republic initiates safeguard investigation on imports of polypropylene bags and tubular fabric, covering the years 2006-2009

Dominican Republic decides to continue investigation and impose preliminary measures of $38 \%$ on imports of polypropylene bags $(6305.33 .90)$ and tubular fabric (5407.20.20), excluding one product category (6305.33.10) due to lack of domestic production. Dominican Republic excludes de minimis suppliers (Colombia, Indonesia, Mexico, and Panama) from the safeguard under Article 9.1.

Dominican Republic decides to impose definitive safeguard measures of $38 \%$ on imports of polypropylene bags (6305.33.90) and tubular fabric (5407.20.20) for 18 months with reductions at 6 months and at 12 months. Dominican Republic excludes de minimis suppliers (Colombia, Indonesia, Mexico, and Panama) from the safeguard under Article 9.1.*

Costa Rica requests dispute settlement consultations with Dominican Republic; Panama later requests to join consultations (22 October) as do Guatemala (October 25), Honduras, and El Salvador (26 October)

Source: Compiled by the authors from publicly available information provided by the USTR and WTO.

"Details of the proposed policy are described in Table 2.

focused primarily on integrating the Dominican Republic into the already agreed-upon CAFTA framework. These talks proceeded rapidly, with an agreement being reached in March 2004. The title of the treaty was amended subsequently to the Dominican Republic-Central America Free Trade Agreement (CAFTA-DR); it was signed by all seven parties on 5 August 2004. With respect to the trade relations between the Dominican Republic and the five Central American countries, CAFTA-DR replaced the original free trade agreement (i.e., CA-DR FTA). CAFTA-DR then went through the requisite treaty ratification procedures in each country.

As Table 1 indicates, the CAFTA-DR entered into force for the United States, El Salvador, Guatemala, Honduras, and Nicaragua in 2006 and entered into force for the Dominican Republic on 1 March 2007. While the CAFTA-DR granted 
Figure 2. Dominican Republic: total goods imports by foreign source, 2002-2011

(a) By value

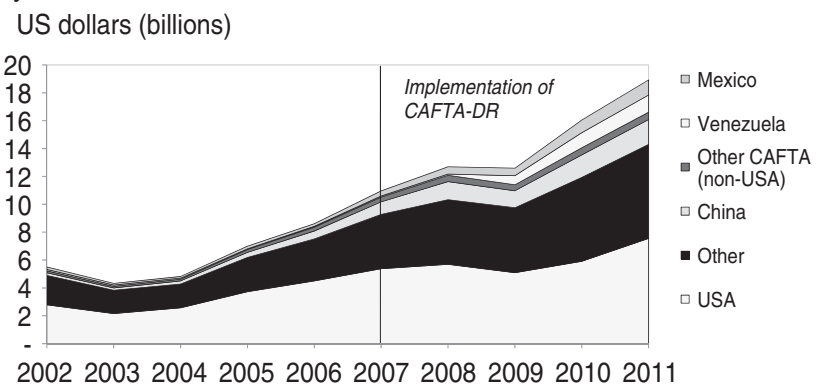

(b) By import market share, selected country groups

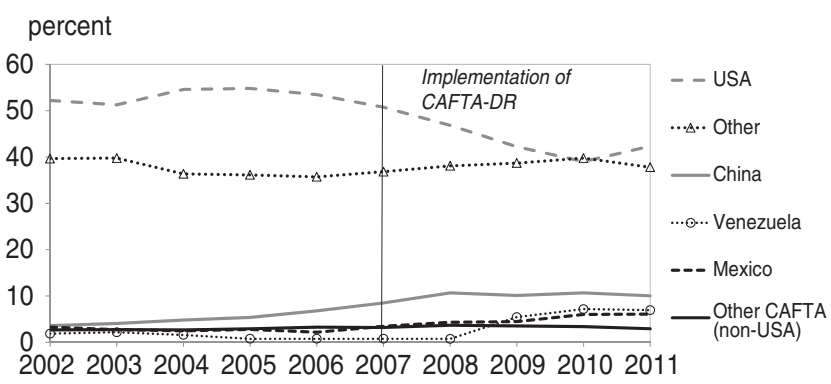

(c) By import market share, CAFTA (non-USA) members

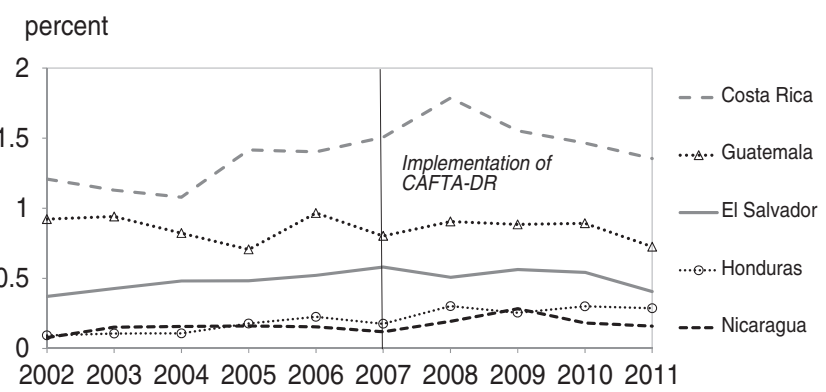

Source: Constructed by the authors with nominal import data from UN Comtrade made available from WITS.

Dominican exporters preferential access to the United States and other key regional markets, it also significantly reduced the Dominican Republic's trade barriers for the six PTA partner countries. As a result of CAFTA-DR, the simple average tariff rate for goods from the US and the five Central American countries fell from the most-favoured-nation (MFN) tariff rate of $8.5 \%$ in 2006 to an average preferential rate of $2.8 \%$ by 2008 and $1.9 \%$ by 2010 .

Not surprisingly, imports into the Dominican Republic rose during this period. Figure 2 provides details of the Dominican Republic's import market for 
merchandise goods over the period 2002-2011, capturing years both before and after the 2007 implementation of CAFTA-DR. Overall imports increased dramatically during this period. Annual imports in 2011 of roughly $\$ 18$ billion were more than three times larger than their 2002 level. During this period, annual nominal import growth averaged $16 \%$ per year.

Not all of the Dominican Republic's rapid import growth during this period stemmed from its CAFTA-DR partners. Despite the Dominican Republic's imports from CAFTA-DR partners nearly tripling in nominal terms over the decade, Figures $2 \mathrm{~b}$ and $2 \mathrm{c}$ illustrate that their share of overall imports did not increase. For example, while imports from the United States increased from \$2.8 billion in 2002 to $\$ 7.6$ billion in 2011 - an increase of over $270 \%$ - the US share of Dominican Republic's total imports actually declined. At their peak, prior to the CAFTA-DR's entry into effect, American goods constituted 55\% of total imports. By 2011, despite the increase in imports in nominal terms, American goods comprised only $42 \%$ of total imports. A similar story holds for imports from the five Central American countries. Figure $2 \mathrm{a}$ demonstrates that the Dominican Republic's collective annual imports from these five countries increased from $\$ 142$ million in 2002 to $\$ 523$ million in 2011. Yet, Figure 2b illustrates that despite this rapid increase, their share of the Dominican Republic's import market remained relatively stable during this period, rising slightly from $2.7 \%$ in 2002 to $2.9 \%$ in 2011 . Figure $2 \mathrm{c}$ indicates only minor variance in the shares of the individual Central American countries.

At the same time that Dominican Republic imports from its CAFTA-DR partners were increasing, so too were imports from non-PTA partners. Figures $2 \mathrm{a}$ and $2 \mathrm{~b}$ indicate that much of the Dominican Republic's overall increase in imports can be traced to substantial growth from China, Venezuela, and Mexico. China increased its share of the Dominican Republic import market from 3.6\% in 2002 to $10.0 \%$ in 2011, Venezuela from $1.9 \%$ to $6.9 \%$, and Mexico from $3.3 \%$ to $6.1 \%$. The increase in imports from Venezuela was mostly due to oil, while that from Mexico was mostly due to oil and electronics. The surge of imports from China, however, can be attributed to a much wider range of manufactured products, including electronics, footwear, and transportation equipment.

Overall, Figures 1 and 2 suggest two important starting points for this particular WTO dispute. First, while the Dominican Republic experienced a large import surge following its decision to join CAFTA-DR (except for a temporary decline during the Great Recession), a significant share of the aggregate increase was not linked to the trade preferences granted under CAFTA-DR. Domestic industries in the Dominican Republic faced increased pressure from two fronts: (1) from American and Central American producers, on account of the lower tariff levels triggered by the PTA, and (2) from Chinese and other foreign producers, on account of their increased competitiveness and other factors, unrelated to any PTA. Demands for additional trade protection may therefore be only partially linked to the PTA. 
Second, the import surge and a rising trade deficit did not take place during a period when the overall Dominican Republic economy was struggling. This is relevant because the use of temporary trade barriers such as safeguards is sometimes triggered by macroeconomic shocks that may arise in the form of increases in unemployment, major declines in GDP growth, or sharp appreciations of the real exchange rate. ${ }^{12}$ The macroeconomic data for the Dominican Republic reveal little evidence of a shock during 2009-2010 surrounding the safeguards investigation at issue in these disputes. Figure 1 indicates the main aggregate-level shock that the Dominican Republic experienced was approximately six years earlier, prior to the start of the CAFTA-DR negotiations. Thus, the overall macroeconomic climate was not likely to be a contributing factor for the Dominican Republic's decision to impose a safeguard in this particular instance. ${ }^{13}$

Because the trigger for the controversial import restriction at issue in these cases was likely market-specific, rather than macroeconomic, the next section investigates the tariff schedules and disaggregated import data for the specific product markets implicated by the applied safeguard under dispute.

\subsection{The Dominican Republic's market for polypropylene bags and tubular fabric}

The safeguard measures that the four Central American countries challenged at the WTO concern two specific product markets - polypropylene bags and tubular fabric. Polypropylene bags encompass a wide range of parcels used for packaging and transportation of goods, from individual shopping bags to heavy-duty packaging used for industrial products (e.g., sand, salt) and agricultural products. Tubular fabric is the woven synthetic material used as an input to produce polypropylene bags.

In its WTO tariff schedule, the Dominican Republic committed to a MFN bound tariff rate of $40 \%$ ad valorem for both polypropylene bags and tubular fabric. The bound tariff rates serve as a maximum ceiling, with WTO members free to implement any applied MFN tariff rate so long as it is below the bound rate.

12 Bown and Crowley (2013b) examine a sample of 18 economies over 1995-2010, including 13 emerging economies, and identify evidence that such macroeconomic shocks trigger new import restrictions under TTB policies such as antidumping and safeguards.

13 During 2009-2010, the Dominican Republic initiated 7 temporary trade barrier investigations, 4 of which resulted in the imposition of final measures. It initiated 5 safeguard investigations, only 2 of which resulted in final measures - the one on polypropylene bags and tubular fabric described in detail in the text, and a separate investigation on socks. The other safeguard investigations concerned imports of bottles, flasks, and other containers, as well as two separate investigations on toilet paper-none of these investigations resulted in imposition of final measures. In 2010, the Dominican Republic initiated one antidumping investigation on imports of steel rods and bars from Turkey and one China-specific transitional safeguard investigation on imports of lavatories and washbasins from China, both of which resulted in imposition of final measures. See Bown (2013). 
Thus, WTO members have the option of unilaterally raising the applied MFN tariff rate to any level below the bound rate. Prior to the entry into force of CAFTADR, the Dominican Republic set its applied MFN tariff rates for both products well below its bound rate of $40 \%$. For tubular fabric (classified under the tariff line 5407.20.20), the applied tariff rate was set at $14 \%$ ad valorem. For polypropylene bags (classified under the tariff line 6305.33 .90 ), it was set at $20 \%$ ad valorem.

After CAFTA-DR's entry into force, the applied tariff rates of $14 \%$ ad valorem for tubular fabric and $20 \%$ ad valorem for polypropylene bags continued to apply for imports from countries that were not part of the PTA (e.g., China, Mexico). However, CAFTA-DR required that the parties to the PTA provide preferential tariff access to each other. Specifically, the PTA stipulated that over a period of twenty years, all tariffs must be eliminated on all products traded between the seven CAFTA-DR countries.

CAFTA-DR provided for eight different staging categories for implementation, with different implications for each staging category as to the timing and level of the required tariff cuts. ${ }^{14}$ Each party must assign each product to a particular staging category. For example, the Dominican Republic designated tubular fabric under Category A, which required that all tariffs be eliminated immediately upon the treaty's entry into force. Polypropylene bags, on the other hand, were placed under Category $\mathrm{C}$, which required that tariffs be gradually eliminated over ten years, with ten equivalent cuts to be made annually. As polypropylene bags had an applied tariff rate of $20 \%$ prior to CAFTA-DR's entry into force, the Dominican Republic was obliged to shave $2 \%$ off the applied rate each year until it was completely eliminated by 1 January of year 10 .

The CAFTA-DR was not the first time that the Dominican Republic had agreed to eliminate tariffs on these products and expose its domestic industry to greater competition from Central American producers. The Dominican Republic had already committed to eliminate tariffs on both polypropylene bags and tubular fabric for its PTA partners as a consequence of the CA-DR FTA that entered into force in 2001. However, the earlier CA-DR FTA mandated that this be done in a series of equal-sized annual cuts enacted over seven years. Thus, CAFTA-DR should not be considered the trigger that opened the door to greater foreign competition in polypropylene bags and tubular fabric from the five Central American countries. CAFTA-DR only changed the timing for the grant of preferential access and tariff elimination, shortening it for tubular fabric (due to

14 For the list of general categories applicable to all parties' tariff schedules, see Annex 3.3, para. 1 of CAFTA-DR. In addition, for specific categories applicable for the Dominican Republic's tariff schedule, see the Dominican Republic's final tariff schedule for CAFTA-DR, available at http://www.ustr.gov/tradeagreements/free-trade-agreements/cafta-dr-dominican-republic-central-america-fta. 
Figure 3. Dominican Republic's imports of polypropylene bags and tubular fabric, 2002-2011

(a) By categories of foreign source countries US dollars (millions)

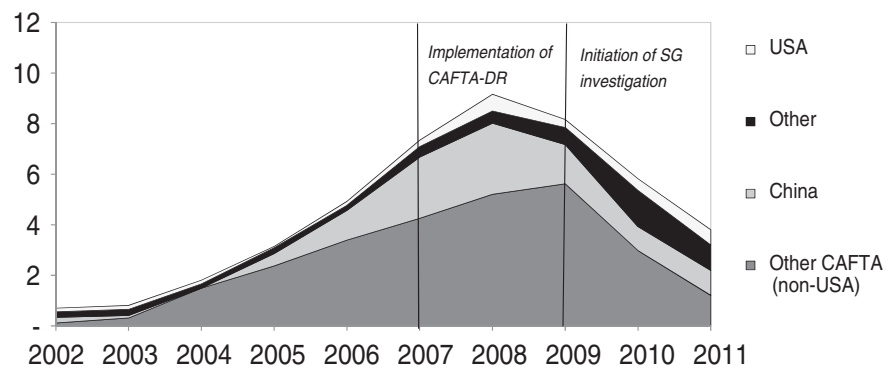

(b) By selected CAFTA member countries US dollars (millions)

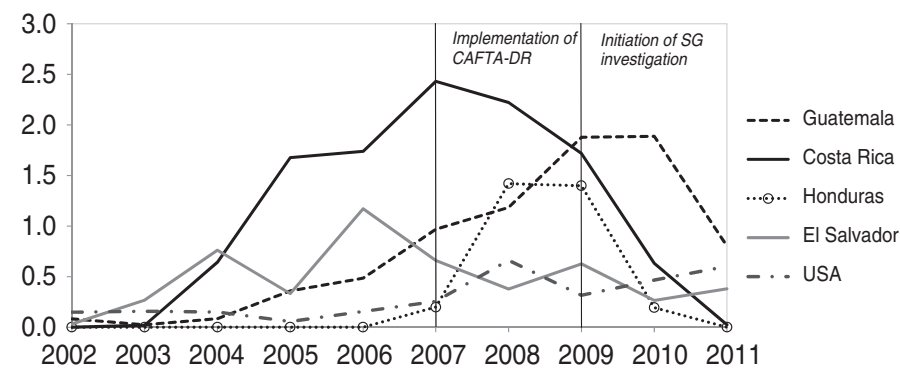

(c) By selected CAFTA non-member countries US dollars (millions)

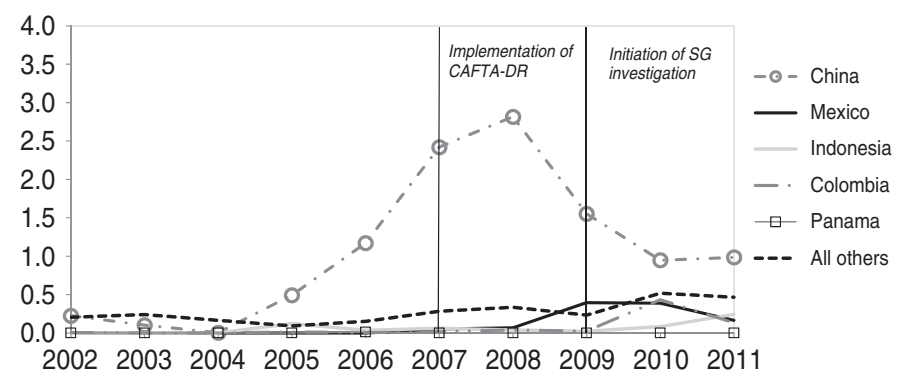

Source: Constructed by the authors with nominal import data at the 6-digit HS level from UN Comtrade made available from WITS.

its placement into Category A) and lengthening it for polypropylene bags (due to its placement into Category C).

Figure 3 examines features of the Dominican Republic's import market for polypropylene bags and tubular fabric in the years prior to and following the 
CAFTA-DR. ${ }^{15}$ Many of the trends for the Dominican Republic's total imports described earlier (see Figure 2) also hold in the context of these two specific product markets. Following the PTA, foreign imports of polypropylene bags and tubular fabric rose dramatically. But so too did imports from non-PTA partners, especially those from China.

Figure $3 \mathrm{a}$ estimates that the value of Dominican Republic imports of these two products from all sources had nearly doubled from $\$ 4.9$ million to $\$ 9.1$ million between 2006 (the year prior to CAFTA-DR's entry into force) and 2008 (the first full year following the reduction of tariffs as required by CAFTA-DR). The chart shows that a sizeable portion of the increase came from the Central American partners to the CAFTA-DR agreement. It also illustrates how, during this period, imports from China also increased significantly.

Figure $3 \mathrm{~b}$ takes a closer look at the import levels from the countries that are members of the CAFTA-DR agreement. Recall that as a result of CAFTA-DR, the Dominican Republic agreed to eliminate tariffs altogether on tubular fabric imported from CAFTA-DR partner countries and to lower gradually the tariffs on polypropylene bags imported from the CAFTA-DR partner countries. Following the PTA, imports of the two product categories from the CAFTA-DR partner countries did grow - from \$3.5 million in 2007 (when CAFTA-DR entered into force) to $\$ 5.9$ million in 2009 (when the domestic industry petitioned the government to impose a safeguard).

However, Figure 3 a shows that total imports of polypropylene bags and tubular fabric from CAFTA-DR countries were already increasing prior to CAFTA-DR's entry into force. From 2007 through 2009, imports followed the same basic growth trajectory seen since 2003, when significant levels of imports first started arriving into the Dominican Republic from the Central American countries. Furthermore, Figure $3 \mathrm{~b}$ shows that the beneficiaries of the preferential market access vary over time. Prior to CAFTA-DR's entry into force in 2007, three Central American countries (Costa Rica, El Salvador, and Guatemala) had taken advantage of the preferential terms of the prior CA-DR FTA to increase their exports of the two products to the Dominican Republic. ${ }^{16}$ Across these three countries, the impact of the latter CAFTA-DR varied greatly. Imports from El Salvador peaked in 2006 at \$1.2 million, prior to CAFTA-DR's entry into force, and then declined. Imports from Costa Rica peaked in 2007 (i.e., the year that CAFTA-DR entered into force)

15 This analysis is conducted at the 6-digit Harmonized System level, which is the most disaggregated data that are consistently publicly available for Dominican Republic for this period. The import restrictions were defined at the 8-digit HS level, so the dollar value estimates presented in the figures and tables are upper bounds for the actual amount of trade impacted. In particular, the Dominican Republic excluded product 6305.33.10 (a variety within the 6-digit category 630533) from the applied safeguard on the grounds that there was no domestic production of this variety.

16 The Dominican Republic did not have any recorded imports from Nicaragua in these product categories during 2002-2011. It also did not have any recorded imports from Honduras in these product categories during 2002-2006. 
at $\$ 2.5$ million and subsequently declined. Imports from Guatemala continued to experience rapid growth following CAFTA-DR's entry into force and nearly doubled from $\$ 0.97$ million in 2007 to $\$ 1.88$ million in 2009. In addition to Guatemala, the other main beneficiary from CAFTA-DR was Honduras. Its exports of the two product categories grew rapidly, from $\$ 0.2$ million in 2007 to $\$ 1.4$ million in 2008 and 2009.

Figure 3c illustrates that not all of the increase in the Dominican Republic's imports of polypropylene bags and tubular fabric during this period was due to growth from CAFTA-DR member countries. Imports from non-PTA partners (such as China) continued to be subject to the same MFN applied tariffs (of $20 \%$ for polypropylene bags or of $14 \%$ for tubular fabric) during this time period; they did not experience any benefits of a tariff reduction. Yet, as Figure 3c highlights, imports from China also surged during this time period - from \$1.2 million in 2006 before the implementation of CAFTA-DR to $\$ 2.8$ million by 2008 after the implementation. ${ }^{17}$ In other words, Chinese products continued to acquire greater market share, even after the PTA placed them at a relative disadvantage compared to their competitors from the CAFTA-DR countries, suggesting an increasing competitiveness of Chinese products in the two categories during this time period. Most importantly, pressure in the Dominican Republic to impose a safeguard was not likely based solely on the negative impact to domestic industry of the preferential tariffs granted in CAFTA-DR.

Thus, the background for this set of disputes is more complex than one might expect. The PTA in effect at the time that the safeguard was implemented (i.e., the CAFTA-DR agreement) does contribute to the domestic industry's declining competitiveness in that it alters the timing of tariff concessions for PTA partners. But analysis of a longer time-horizon of data suggests CAFTA-DR is not likely the key triggering event - indeed, the initial forces were set in motion long before this PTA was negotiated. They include a prior PTA (i.e., the CA-DR FTA) implemented in late 2001, which had granted the first set of tariff concessions that led to accelerating imports, as well as China's WTO accession in 2001 and the strengthening of its export competitiveness. Thus, the safeguard measures at issue resulted from a series of economic developments that transpired over the better part of a decade.

\subsection{The Dominican Republic's safeguard on polypropylene bags and tubular fabric}

Faced with increased pressure from foreign imports, a domestic producer, Fertilizantes Santo Domingo C. por A. (FERSAN), filed a petition in July 2009

17 Besides China, imports from other countries-such as Colombia, Indonesia, Mexico, and Panama-also increased slightly in some instances during the period of 2006-2009. However, as Figure 3c shows, they remained at relatively low levels of less than $\$ 500,000$ annually. 
Table 2. Dominican Republic: trade policies toward polypropylene bags and tubular fabric

Tariff binding rate

Applied MFN tariff rate in 2005

Applied MFN tariff rate in 2008

CAFTA-DR tariff in 2008

Structure of proposed 'safeguard,' the full ad valorem tariff

covering 18 October 2010-18 April 2011

toward CAFTA-DR countries

toward Colombia, Indonesia, Mexico, Panama

toward all others

covering 19 April 2011-19 October 2011

toward CAFTA-DR countries

toward Colombia, Indonesia, Mexico, Panama

toward all others

covering 20 October 2011-20 April 2012

toward CAFTA-DR countries

toward Colombia, Indonesia, Mexico, Panama

toward all others

covering the period beginning 21 April 2012

toward CAFTA-DR countries

toward Colombia, Indonesia, Mexico, Panama

toward all others
40.0

$20.0 *$

20.0

14.0

38.0

20.0

38.0

28.0

20.0

28.0

20.0

20.0

20.0

0.0

20.0

20.0
40.0

14.0

14.0

0.0

38.0

14.0

38.0

28.0

14.0

28.0

14.0

14.0

14.0

0.0

14.0

14.0

Source: Compiled by the authors from the WTO Integrated Data Base, TRAINS, and the WTO Consolidated Tariff Schedules database.

requesting that the government of the Dominican Republic initiate a safeguard investigation on imports of polypropylene bags and tubular fabric. Five months later, on 15 December 2009, the government announced that it would begin such an investigation. Under the Dominican Republic's domestic legislation on safeguards, the Commission for the Regulation of Unfair Trade Practices and Safeguard Measures ('the Commission') was responsible for carrying out the investigation request and determining whether the petition should be granted.

Table 2 summarizes information on the import restricting policies relating to these two products around this time period. First, recall that the Dominican Republic's WTO tariff binding was $40 \%$ for both tubular fabric and polypropylene bags. Before the CAFTA-DR was implemented in 2007, the Dominican Republic applied a MFN tariff of $14 \%$ on all foreign imports of tubular fabric. The tariff on this product was cut to zero for CAFTA-DR trading partners on 1 March 2007, but 
remained at $14 \%$ for all other countries. Also, before CAFTA-DR, the Dominican Republic applied a MFN tariff of $20 \%$ on all imports of polypropylene bags. As of 1 March 2007, the Dominican Republic was required to cut this tariff rate preferentially by 2 percentage points annually on a ten-year harmonized schedule. ${ }^{18}$

The FERSAN safeguard petition requested that the Dominican Republic raise the tariff rate for both polypropylene bags and tubular fabric to $74.3 \%$ ad valorem for three years. ${ }^{19}$ On 16 March 2010, the Commission issued a preliminary report in which it authorized the imposition of a provisional safeguard measure for up to 200 days while it continued its safeguard investigation. The provisional safeguard raised the tariff rate for both polypropylene bags and tubular fabric to $38 \%$ ad valorem. ${ }^{20}$ Imports from Colombia, Indonesia, Mexico, and Panama were to be excluded from the safeguard, pursuant to Article 9.1 of the Agreement on Safeguards, which permits exclusion of imports originating in a developing country whose import share does not exceed 3\%. The FERSAN petition had also requested that a safeguard be applied for polyethylene bags, but the Commission declined to raise tariffs for this product on the grounds that the domestic producer did not produce such bags. Ten days later, on 26 March 2010, the Dominican Republic notified the WTO Committee on Safeguards of the adoption of the provisional safeguard. 21

On 5 October 2010, the Commission issued its final decision in which it decided to apply a definitive duty of $38 \%$ ad valorem on polypropylene bags and tubular fabric. The final decision reaffirmed that imports from Colombia, Indonesia, Mexico, and Panama were to be excluded from the safeguard, pursuant to Article 9.1 of the Agreement on Safeguards. The original final decision set forth a timetable for two subsequent phased reductions of the tariff rates under the safeguard. First, on 19 April 2011, the safeguard tariff rates would be lowered from $38 \%$ to $28 \%$ for both products. Then, on 20 October 2011 , they would again be

18 Because CAFTA-DR entered into force in 2006 for several of the member countries (albeit not the Dominican Republic, for which CAFTA-DR only entered into force in March 2007), that year is considered Year 1 for purposes of the ten-year period during which import tariffs for polypropylene bags would be eliminated.

19 The petition also requested the imposition of a provisional safeguard, whereby a tariff rate of $40 \%$ ad valorem would be applied for no more than six months prior to the imposition of the definitive safeguard. See Panel Report, Dominican Republic-Safeguard Measures on Imports of Polypropylene Bags and Tubular Fabric, WT/DS415/R, WT/DS416/R, WT/DS417/R, WT/DS418/R, adopted 22 February 2012, para. 2.12 (hereinafter Panel Report, Dominican Republic-Safeguard Measures).

20 Ibid., para. 2.16.

21 See Communication from the Dominican Republic to the Committee on Safeguards, Notification under Article 12.4 of the Agreement on Safeguards before Taking a Provisional Safeguard Measure Referred to in Article 6, Notification under Article 12.1(b) of the Agreement on Safeguards on Finding Serious Injury or Threat Thereof Caused by Increased Imports, Notification Pursuant to Article 9, Footnote 2, of the Agreement on Safeguards (Tubular Fabric and Polypropylene Bags), G/SG/N/7/DOM/1, G/SG/N/8/DOM/1, G/SG/N/11/DOM/1, 6 April 2010. 
lowered down to the original applied tariff rates of $20 \%$ for polypropylene bags and $14 \%$ for tubular fabric. The safeguards would end completely on 21 April 2012, after which imports from CAFTA-DR countries would once again be subject to the preferential rates to which they were entitled under the PTA. Again, the Dominican Republic informed the WTO Committee on Safeguards of the definitive safeguard; notification was provided on 8 October 2010 shortly after the final decision was issued. ${ }^{22}$

However, on 17 October 2011, three days before the second reduction was due to take effect, the Commission issued an Interim Report in which it noted that the decision had been revised so as not to implement the second phased reduction. This meant that the tariff rates would remain at 28\% until 21 April 2012 for imports of both products, unless they were sourced from one of the exempted developing countries.

Four points are worth noting about the Dominican Republic's handling of the safeguards investigation. First, although the government did assent to the domestic industry's request that a safeguard be imposed, the final terms imposed were much less than what FERSAN had initially sought. Recall that FERSAN's petition requested a safeguard tariff rate of $74.3 \%$ ad valorem, which is well in excess of the Dominican Republic's bound tariff commitment of $40 \%$. However, the Commission only agreed to impose a definitive safeguard tariff rate of $38 \%$. This decision sets up the unique fact pattern - the tariff rate applied under the safeguard is below that of the country's commitment for its bound tariff rate. In most instances, the safeguard tariff rate exceeds the bound tariff rate; indeed, this is what the domestic industry sought in this case. However, the government's decision not to grant the full terms of the domestic industry's request led to a situation whereby the particular safeguard differed from most imposed by WTO members.

Second, a natural question that then follows is why it was necessary for the Dominican Republic to impose a safeguard at all. After all, a WTO member can raise its applied MFN tariff with impunity so long as the new rate remains below the bound rate. Here, that would appear to be the case; the desired adjusted applied tariff level $(38 \%)$ remained below the bound tariff rate $(40 \%)$. One key reason why the Dominican Republic may have considered it necessary to use the safeguard mechanism to raise the applied tariff level in this case was its desire to also ensure that the $38 \%$ tariff rate would be applied against its PTA partners. Had it simply raised the applied MFN tariff rate, its Central American trading partners would

22 See Communication from the Dominican Republic to the Committee on Safeguards, Notification under Article 12.1(b) of the Agreement on Safeguards upon Making a Finding of Serious Injury or Threat Thereof Caused by Increased Imports, Notification under Article 12.1(c) of the Agreement on Safeguards, Notification Under Article 9, Footnote 2, of the Agreement on Safeguards (Tubular Fabric and Polypropylene Bags), G/SG/N/8/DOM/1/Suppl.2, G/SG/N/10/DOM/1, G/SG/N/11/DOM/1/Suppl. 1, 18 October 2010. 
have continued to demand the tariff concessions required under the CAFTA-DR by asserting that the PTA served as an exception to MFN treatment pursuant to GATT Article XXIV. While the domestic industry and government authorities chose to circumvent the PTA tariff concessions by applying a safeguard, below we identify other available alternative policy instruments.

Third, the 'behaviour' of the Dominican Republic's government at the time certainly suggests that it considered the increase to its applied tariff level to be a safeguard measure. The government notified both the provisional and final measures to the WTO Committee on Safeguards, and it invoked Article 9.1 of the Agreement on Safeguards so as to exclude the four de minimis supplier developing countries. These are signs that the government considered itself bound by the terms of its WTO treaty commitments on safeguards in applying its measure.

Finally, the imposition of the safeguard measure coincides with a dramatic decline in Dominican Republic imports of the affected products, as shown in Figure 3. Nevertheless, because the safeguard measures took effect during the midst of the Great Recession of 2009-2010 when overall global trade flows shrank dramatically, it is difficult to discern just how much of the import decline in this period is due specifically to the safeguard. The potency of the safeguard measures is, however, reflected in the fact that even when the global economy recovered in 2011, imports did not rebound.

\subsection{The WTO challenge}

The actions of the Dominican Republic concerning these safeguards were being monitored closely by its Central American trading partners. On 15 October 2010, only ten days after the Dominican Republic issued its final decision, Costa Rica and Guatemala separately requested WTO consultations with the Dominican Republic over the safeguard measures. Three days later, Honduras also filed a request for WTO consultations; El Salvador followed the next day. The four Central American countries subsequently requested to join each others' consultations. ${ }^{23}$

Why were the Central American countries so quick to file WTO cases against the Dominican Republic? Figure 4 provides one explanation by showing the economic importance of the Dominican Republic's market for these countries' exporters of polypropylene bags and tubular fabric. It plots the share of each country's exports of those two products to the Dominican Republic relative to the country's total global exports of those products. In 2009, roughly $40 \%$ of the total global exports of these two goods from Costa Rica, El Salvador, and Honduras were destined for the Dominican Republic. Note that even though the total volume of

23 Panama also requested to join all four consultations. Recall that Panama was one of the four developing countries whose imports were excluded from the safeguard measures. The consultation requests were all accepted by the Dominican Republic. 
Figure 4. The importance of the Dominican Republic's export market for polypropylene bags and tubular fabric for selected countries' exporters, 2002-2011

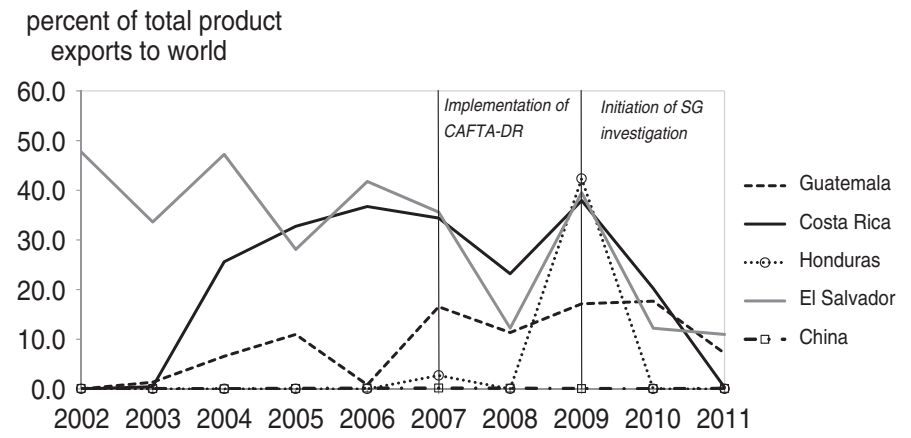

Source: Constructed by the authors with nominal export data at the 6-digit HS level from UN Comtrade made available from WITS. Share of each country's total exports of polypropylene bags and tubular fabric that were exported to the Dominican Republic.

Costa Rican and Salvadoran exports had declined following CAFTA-DR (as mentioned earlier and illustrated in Figure 3b), the Dominican Republic remained a key export market for both countries. Also, $17 \%$ of Guatemala's total exports of the two markets were shipped to the Dominican Republic. ${ }^{24}$

By contrast, Figure 4 also reveals that the Dominican Republic's market was never more than $0.2 \%$ of China's global exports of these two products during this period. In absolute terms, Figure 3 illustrated that China was the largest exporter of the two products to the Dominican Republic in 2008, the year prior to the filing of the safeguards petition. Thus, even though its producers were also adversely affected by the safeguard measures, China did not deem it worthwhile to expend its limited WTO litigation resources to file a separate case against the Dominican Republic; instead it participated in the other disputes as an interested third party. ${ }^{25}$

The four complainants asserted violations of GATT Article XIX and several provisions of the Agreement on Safeguards. ${ }^{26}$ They alleged that the Dominican Republic failed to satisfy several requirements that WTO law mandates as

24 Bown and McCulloch (2010) also identify a number of other formal disputes involving one (or more) developing country complainants challenging a developing country respondent, frequently through subsidized legal assistance provided by the Advisory Centre on WTO Law (ACWL). Indeed, the ACWL provided assistance to the complainants in this particular dispute, and a law firm from the ACWL's Roster of External Counsel provided assistance to the respondent (Dominican Republic).

25 This is a common practice for China, as reflected by the fact that it has participated as a third party in 100 cases as of August 2013, which is the fourth highest of all WTO members (behind the EU, Japan, and the US).

26 Specifically, the complainants alleged violations of Articles 2.1, 3.1, 4.1, 4.2, 5.1, 6, 8.1, 9.1, 11.1, and 12 of the Agreement on Safeguards. 
necessary for any WTO member wishing to impose a safeguard, including demonstration of (1) an 'unforeseen development'; (2) an increase in imports; (3) serious injury to the domestic industry; and (4) a causal link between the increased imports and serious injury. In addition, they asserted that the Dominican Republic, in the process of excluding certain developing countries from the safeguards, failed to comply with the parallelism principle of WTO law and acted inconsistently with its obligations under the Agreement on Safeguards.

Because the tariff rates imposed under the safeguard on polypropylene bags and tubular fabric fell below the bound tariff rates to which the Dominican Republic had committed in its WTO schedule, the complainants worried that the WTO might find GATT Article XIX and the Agreement on Safeguards to be inapplicable. Should that be the case, the complainants offered two arguments in the alternative. First, they asserted that the Dominican Republic's safeguard measures violate GATT Article I:1, requiring MFN treatment. Second, they asserted that the safeguard measures represent duties and charges other than ordinary customs duties in violation of GATT Article II: 1.

The four complainants, along with Panama, held consultations with the Dominican Republic on 16-17 November 2010. As these consultations failed to reach a solution, each of the four Central American countries filed separate requests in mid-December 2010 for the WTO to establish a Panel. At its meeting on 7 February 2011, the WTO Dispute Settlement Body decided to establish a single Panel to hear all four disputes, pursuant to Article 9.1 of the Dispute Settlement Understanding. On 11 March 2011, the WTO Director-General composed the Panel, with Pierre Pettigrew, Canada's former Minister for International Trade and Minister of Foreign Affairs, serving as the Chairperson. ${ }^{27}$ The Panel decided that Spanish would serve as the working language for its proceedings. Seven other countries participated as third parties in the dispute. ${ }^{28}$

On 31 January 2012, the WTO Panel issued a single final report that addressed all four complaints. The Panel held that GATT Article XIX and the Agreement on Safeguards were applicable to the measure at hand. The Panel then found the Dominican Republic to be in violation of various provisions in these agreements because it had failed to satisfy the 'unforeseen development' and 'serious injury' requirements and incorrectly defined the 'domestic industry' as part of its investigation. However, the Panel rejected the claims made by the complainants

27 The other Panel members were Ms Enie Neri de Ross, a partner at the law firm of Baker \& McKenzie in Caracas and a former representative of Venezuela to the Antidumping, Subsidies and Countervailing Duties, and Safeguards Committees of the WTO, and Ms Gisela Bolivar, a partner at Jiménez Romero y Asociados in Mexico City.

28 The third party participants were China, Colombia, the EU, Nicaragua, Panama, Turkey, and the US. Third parties had the option of making their presentations in English, French, or Spanish. Six of the third-party participants made written submissions (the exception being China) and five made oral presentations (the exceptions being China and Nicaragua). See Panel Report, Dominican RepublicSafeguard Measures, paras. 1.9-1.10. 
that the Dominican Republic had failed to satisfy its requirements with respect to a showing of an increase in imports and causation. Finally, the Panel held that the Dominican Republic, in its treatment of developing countries excluded from the safeguard, did not act inconsistently with respect to the parallelism requirement. However, the Panel found that the Dominican Republic violated Article 9.1 of the Agreement on Safeguards because of its failure take all reasonable measures available to exclude certain developing countries (namely, Thailand) from the safeguard measures.

The Dominican Republic chose not to appeal the Panel's report. On 22 February 2012, the WTO Dispute Settlement Body (DSB) adopted the decision. On 23 March 2012, the Dominican Republic informed the DSB that it would bring its safeguard measure in conformity with the Panel report. The safeguard measures on polypropylene bags and tubular fabric were lifted on 21 April 2012, bringing a formal end to the dispute.

\section{Analysis of the Panel decision}

This section analyses the Panel's rulings on four previously unresolved issues in WTO law: (1) whether a policy that does not contravene a WTO member's commitments on bound tariffs, quotas, or quantitative restrictions may nevertheless be considered a safeguard; (2) whether the tariff concessions made in a PTA or associated with China's WTO accession may be considered an 'unforeseen development' justifying the imposition of a general safeguard; (3) whether the parallelism principle extends to a WTO member's exclusion of de minimis imports from certain developing countries pursuant to Article 9.1 of the Agreement on Safeguards; and (4) whether a WTO member may selectively decide which developing countries' de minimis imports should be excluded pursuant to Article 9.1 of the Agreement on Safeguards.

Our overall assessment of the Panel's decision is generally positive. We contend that the Panel provided substantial clarity in their ruling on all four questions. This in turn, it is hoped, will cause other WTO members to be more cautious in selectively applying a safeguard to escape trade concessions made in a PTA.

\subsection{When is a measure not a safeguard? The scope of potential safeguard violations}

The Panel clarified a threshold question of what types of policy measures ought to be considered a safeguard. Previous WTO cases concerned challenges of instances where a WTO member resorted to a safeguard in order to raise its applied tariff level above the bound tariff commitment. However, the fact pattern in the current cases is different. Recall that the Dominican Republic had bound the tariff lines for polypropylene bags and tubular fabric at $40 \%$ ad valorem. While the domestic petitioner, FERSAN, had requested a safeguard tariff rate in excess of this rate, the government instead set the rate at $38 \%$ ad valorem - i.e., at a level below the bound 
rate. These disputes therefore raise the interesting question of whether a policy measure may constitute an illegal safeguard even if the applied tariff rate imposed by the safeguard does not contravene the bound tariff rate in the WTO member's Schedule (or its commitments on quotas and other quantitative restrictions).

GATT Article XIX:1(a) states:

If, as a result of unforeseen developments and of the effect of the obligations incurred by a Member under this Agreement, including tariff concessions, any product is being imported into the territory of that contracting party in such increased quantities and under such conditions as to cause or threaten serious injury to domestic producers in that territory of like or directly competitive products, the Member shall be free, in respect of such product, and to the extent and for such time as may be necessary to prevent or remedy such injury, to suspend the obligation in whole or in part or to withdraw or modify the concession. (Emphasis added by Panel)

Following the Uruguay Round, any policy measure that falls under GATT Article XIX is also subject to the treaty requirements of the WTO's Agreement on Safeguards.

The Dominican Republic's defence rested on the last part of GATT Article XIX:1(a). The sentence makes reference to the two types of actions that a WTO member, experiencing the conditions defined in the first part of the provision, is allowed to take when implementing a safeguard. First, a WTO member imposing a safeguard may suspend a WTO obligation in whole or in part. Second, it may withdraw or modify a WTO concession. The Dominican Republic noted that it did neither. It asserted that its actions therefore did not qualify as a safeguard and were not subject to GATT Article XIX or the Agreement on Safeguards.

Note the creative legal manoeuvres made by the Dominican Republic in making its defence. During the course of conducting its investigation of the foreign importers, the government had conducted the domestic administrative proceedings as governed by its domestic law and regulations on safeguards. ${ }^{29}$ After accepting the FERSAN petition, it had issued a notice informing the public that it was to conduct a general safeguard investigation. ${ }^{30}$ The government then took care to inform the WTO Committee on Safeguards that it was initiating a safeguard investigation. ${ }^{31}$ After the Commission ruled in favour of the domestic petitioner

29 These are Law No. 1-02 on Unfair Trade Practices and Safeguard Measures and the Implementing Regulations of Law No. 1-02, which constitute the domestic implementing legislation of the Agreement on Safeguards and GATT Article XIX for the Dominican Republic.

30 Panel Report, Dominican Republic-Safeguard Measures, para. 2.12 and note 32 (citing the Commission's notice of 15 December 2009, published on 17 December 2009).

31 See Communication from the Dominican Republic to the Committee on Safeguards, Notification under Article 12.1(a) of the Agreement on Safeguards on Initiation of an Investigation and the Reasons for It (Polypropylene Bags and Tubular Fabric), G/SG/N/6/DOM/3, 14 January 2010, supplemented by G/SG/ N/6/DOM/3/Suppl.1, 25 January 2010. 
and decided to raise the applied tariff level to $38 \%$, the government again published notices describing its policy measures as a safeguard. ${ }^{32}$ After the Commission decisions were reached, the government provided notice to the WTO Committee on Safeguards on two occasions: (1) following the imposition of the provisional safeguard in March 2010; and (2) following the imposition of the definitive measure in October 2010. Nevertheless, ex post the Dominican Republic asserted that the policy measure that it had enacted was actually not a safeguard.

How did it try to justify this argument? Recall that pursuant to GATT Article XIX:1(a), a WTO member enacting a safeguard action either suspends a WTO obligation in whole or in part, or withdraws or modifies a WTO concession. On the latter, the Dominican Republic noted that its applied tariff rate (at 38\%) remained below the bound rate (of $40 \%$ ). Hence, it did not 'withdraw or modify the concession'. This part of its argument went unchallenged by the complainants.

The key question confronting the Panel, therefore, was whether the Dominican Republic's actions amounted to a suspension of a WTO obligation in whole or in part. The Dominican Republic argued that the scope of the term 'obligation' should be understood narrowly as limited to tariff concessions made in accordance with GATT Article II:1 and commitments on quantitative restrictions made in accordance with GATT Article XI. ${ }^{33}$ However, the complainants argued that the term 'obligation' should be interpreted broadly to encompass other treaty obligations made through the WTO regime beyond that of tariffs and quantitative restrictions.

To resolve this question, the Panel examined the textual basis of the term 'obligation' as construed in all three official WTO languages. After doing so, the Panel sided with the complainants; it determined that the term should be interpreted broadly. The Panel noted that nothing in the text expressly limited the scope of the term 'obligation' as referenced in GATT Article XIX. ${ }^{34}$ Therefore, so long as a WTO member's action taken pursuant to a safeguard investigation results in the suspension of a treaty obligation made under the WTO regime, it is governed by GATT Article XIX and the Agreement on Safeguards.

This ruling by the Panel provides an important clarification that a WTO member may contravene WTO law on safeguards even if the measure taken is entirely consistent with its bound tariff schedule and with its obligations on quotas and other quantitative restrictions. In other words, while those may be the most common obligations which WTO members may seek to escape through the implementation of a safeguard, they are not the only ones that are subject to WTO rules.

In this particular instance, the measure implemented by the Dominican Republic suspends the obligation under GATT Article I to provide MFN treatment.

32 Panel Report, Dominican Republic-Safeguard Measures, paras. 2.16 and 2.21 and notes 38 and 44. 33 Ibid., para. 7.26 .

34 Ibid., para. 7.64 . 
Recall that the higher tariff rates applied to all WTO members except for the four excluded developing countries. Consequently, the Panel ruled that the policy measure enacted by the Dominican Republic was a safeguard and therefore bound by the requirements of the GATT Article XIX and the Agreement on Safeguards. ${ }^{35}$

The Panel's ruling on this point strikes us as correct. The Dominican Republic had argued that to interpret the scope of the term 'obligation' to be broader than GATT Articles II (tariff concessions) and XI (quantitative restrictions) would lead to a tension in the ability to reconcile GATT Article XIX with Article 2.2 of the Agreement on Safeguards. The latter provision states that safeguard measures 'shall be applied to a product being imported irrespective of source'. But as the Panel rightly notes, no such tension exists. ${ }^{36}$

While Article 2.2 requires non-discriminatory application of a safeguard, Article 9.1 of the same agreement provides WTO members with an exemption to this obligation. It mandates that WTO members should not apply a safeguard measure to imports from certain developing countries if any individual countries' market share of imports of the concerned product does not exceed 3\% and their collective share does not exceed 9\%. As a result, Article 9.1 should be read as a waiver to the Article 2.2 obligation. And, hence, the scope of the term 'obligation' in GATT Article XIX should be interpreted more broadly to encompass all WTO obligations, including the MFN obligation.

Moreover, the Panel's ruling prevents a WTO member from treating a policy measure as though it were a safeguard and then escaping from its WTO obligations by simply declaring, in the end, that the measure was not a safeguard. Beyond the various public declarations already noted above, the Dominican Republic had resorted to Article 9.1 of the Agreement on Safeguards as the operative rationale for excluding the imports from the four developing countries from the safeguard. Furthermore, in its final decision for the administrative case, the government made clear that the measure being implemented did not replace the normal tariff; instead, it was a temporary measure that would be subject to regular reductions every six months. ${ }^{37}$ Each action suggests the government considered the measure to be a safeguard. Only when it was accused of violating WTO law governing safeguard measures did the government backtrack and declare otherwise.

To be clear, we are not suggesting that the WTO adopt a formalistic test whereby it considers the government's own nomenclature and its notification record as part of the inquiry as to whether a given tariff measure constitutes a safeguard. Instead, we note simply that the prior actions of the Dominican Republic lend weight to the Panel's rationale on this key question. 
What matters in the end is not simply the question of whether the measure triggers an applied tariff rate that is higher or lower than the bound rate. Even when the bound tariff rate is not exceeded, if the measure results in a discriminatory application of the tariff rate which cannot be justified except through recourse to Article 9 of the Agreement on Safeguards, then the measure is a safeguard. Such a measure is therefore subject to the full set of treaty requirements established in the GATT 1994 and the Agreement on Safeguards. In our view, the Panel correctly took advantage of the unique facts of this set of cases to establish this important legal principle.

\subsection{The 'unforeseen developments' requirement: do China's WTO accession and/or PTA concessions qualify?}

The Dominican Republic-Safeguard Measures cases also provided additional clarity on a second legal issue - the 'unforeseen development' requirement of a safeguard. This requirement, contained within GATT Article XIX but not the Agreement on Safeguards, has been much maligned by academic scholars. ${ }^{38}$ Yet, past WTO jurisprudence has made clear that demonstration of the existence of an unforeseen development is a prerequisite for imposing a safeguard. ${ }^{39}$

This requirement presented the Dominican Republic with substantial difficulty, which may help explain its legal strategy of asserting that its policy measure was not a safeguard. Having failed, the Dominican Republic was confronted with the question of how to rebut the complainants' argument that it failed to meet the 'unforeseen development' requirement of GATT Article XIX.

Here as well the Dominican Republic adopted a rather aggressive legal strategy. It first tried to tempt the Panel into ignoring the 'unforeseen development' requirement altogether. Given the widespread criticism that this requirement has encountered, especially within academic circles, perhaps the Dominican Republic hoped that the Panel would courageously challenge past $\mathrm{AB}$ rulings and force the $\mathrm{AB}$ to re-examine this doctrine. After all, past Panels have done so on other AB rulings, including the politically controversial concept of 'zeroing' in antidumping cases. ${ }^{40}$

38 See, e.g., Sykes (2003, 2004); Grossman and Sykes (2006); Wauters (2010).

39 See Appellate Body Report, Korea-Definitive Safeguard Measures on Imports of Certain Dairy Products, WT/DS98/AB/R, adopted 12 January 2000, paras. 74-90; Appellate Body Report, ArgentinaFootwear (EC), paras. 82-97. The Appellate Body has emphasized its jurisprudence from these cases in subsequent safeguards cases. See, for example, Appellate Body Report, United States - Safeguard Measures on Imports of Fresh, Chilled or Frozen Lamb from New Zealand and Australia, WT/DS177/AB/R, WT/ DS178/AB/R, adopted 16 May 2001, para. 72 (hereinafter US-Lamb Safeguards); Appellate Body Report, United States - Definitive Safeguard Measures on Imports of Certain Steel Products, WT/DS248/AB/R, WT/DS249/AB/R, WT/DS251/AB/R, WT/DS252/AB/R, WT/DS253/AB/R, WT/DS254/AB/R, WT/DS258/ $\mathrm{AB} / \mathrm{R}, \mathrm{WT} / \mathrm{DS} 259 / \mathrm{AB} / \mathrm{R}$, adopted 10 December 2003, at para. 273 (hereinafter US-Steel Safeguards).

40 This is the most prominent example in which Panels have challenged the Appellate Body's rulings that the practice is illegal, only to be overturned. See, for example, Panel Report, United States - Measures Relating to Zeroing and Sunset Reviews, WT/DS322/R, adopted 23 January 2007, as modified by Appellate Body Report, WT/DS322/AB/R, adopted 23 January 2007; Panel Report, United States - Final 
Furthermore, the $\mathrm{AB}$ had not examined the 'unforeseen development' requirement since 2003 in the US-Steel Safeguards disputes. ${ }^{41}$ Perhaps since the composition of the $\mathrm{AB}$ had completely turned over and there had been persistent academic criticism, these disputes might serve as the vehicle for the WTO to undo the 'unforeseen developments' requirement for safeguards. ${ }^{42}$

The Dominican Republic advanced two arguments in support of the proposition that the 'unforeseen development' requirement established in prior $\mathrm{AB}$ case law should be eliminated. First, it noted that the Agreement on Safeguards omits the 'unforeseen development' language found in GATT Article XIX. Because the Agreement on Safeguards is 'a more specific and subsequent agreement,' its requirements ought to trump the contrary provisions of GATT Article XIX. ${ }^{43}$ Beyond advancing this argument based on lex specialis and lex posterior derogat priori, the Dominican Republic put forward a second argument, just in case the Panel felt the need to resort to Article 32 of Vienna Convention on the Law of Treaties to determine this legal question. This argument furthermore noted that the negotiating history of the Uruguay Round reveals the intention of the parties to eliminate the 'unforeseen development' requirement. The Dominican Republic drew attention to the fact that negotiators had included a clause relating to the concept of an 'unforeseen development' in an earlier 1989 draft text of the Agreement on Safeguards, but then subsequently deleted it for the final version. ${ }^{44}$

The Panel however refused to take the bait. It remarked that the "Appellate Body has made it clear that Article XIX of the GATT 1994 and the Agreement on Safeguards are to be applied cumulatively' and that while past $\mathrm{AB}$ decisions are not binding because WTO dispute settlement is not based on a system of precedents, nevertheless, past 'reports adopted by the Dispute Settlement Body create legitimate expectations'. ${ }^{45}$ The Panel therefore refused to deviate from past $\mathrm{AB}$ interpretation unless convincing arguments were made for a departure; in this instance, it found that the Dominican Republic had not made such a case. ${ }^{46}$

Having failed to convince the Panel to reopen the question of whether the 'unforeseen developments' requirement was legitimate, the Dominican Republic then was forced to prove the existence of 'unforeseen developments' necessitating the imposition of a safeguard. It offered two 'unforeseen developments': the entry

Anti-Dumping Measures on Stainless Steel from Mexico, WT/DS344/R, adopted 20 May 2008, as modified by Appellate Body Report, WT/DS344/AB/R, adopted 20 May 2008. Bown and Prusa (2011) provide an analysis.

41 Appellate Body Report, US-Steel Safeguards, paras. 269-330.

42 The last members of the Appellate Body who had served during the US-Steel Safeguards cases were Luiz Olavo Baptista and Georgio Sacerdoti, both of whom stepped down in 2009 upon completion of their second four-year term.

43 Panel Report, Dominican Republic-Safeguard Measures, para. 7.119 and note 191.

44 See ibid.

45 Ibid., para. 7.128-129.

46 Ibid. para. 7.129. 
of China into the WTO; and the process of tariff reduction that accompanied the entry into force of CAFTA-DR and the Central America-Dominican Republic FTA. ${ }^{47}$ The Panel's rulings on both arguments break new legal ground.

First, to the best of our knowledge, these disputes mark the first time that a WTO member has argued that the impact of China's WTO entry can serve as an unforeseen development necessitating the imposition of a WTO global safeguard. The Panel dismissed the Dominican Republic's argument, noting that the investigation report failed to explain how the increase in imports was a result of China's WTO accession and its subsequent effect on international trade, or why these events could not have been foreseen. ${ }^{48}$

Consider that China first notified the GATT of its desire to resume its status as a contracting party in 1986 . While China's formal accession did not occur until fifteen years later, the Dominican Republic could have reasonably foreseen this possibility at the time of its own accession to the WTO in 1995 which allowed it, as an existing member, to influence the terms of China's ultimate WTO accession in 2001. Although accession talks stalled following the 1989 Tiananmen Square crackdown, by 1995, China had once again embarked on a reform-oriented strategy to reintegrate itself into the global economy. Furthermore, to the extent that the respondent's argument does not concern China's accession itself, but rather the effect of China's accession, WTO members created an unprecedented countryspecific safeguard to address such effects. Had the WTO intended for the global safeguard mechanism to be used for such instances, the creation of a China-specific safeguard would not have been necessary.

The Panel then turned to the Dominican Republic's second argument - that the tariff reductions accompanying the CAFTA-DR trade agreement served as an unforeseen development. Again, to the best of our knowledge, no WTO member had previously asserted that the tariff reductions accompanying a PTA serve as the basis for an unforeseen development necessitating a safeguard. We are also doubtful that such an argument can pass muster under the WTO's 'unforeseen development' test and again applaud the Panel for rejecting it. In principle, each WTO member could have foreseen the possibility that it might enter into a PTA at the time it voluntarily made its tariff concessions. In stipulating the conditions under which a WTO member may enter into a PTA, GATT Article XXIV explicitly foreshadows this possibility. Moreover, unlike other unforeseen developments, the tariff concessions made under a PTA are not the consequence of an exogenous shock outside of the country's control. Instead, it is an endogenous choice made by the country itself. If further tariff concessions resulting from the PTA lead to unanticipated consequences, then the proper place to exercise a safeguard to seek temporary escape from the concession would be the PTA itself and not the WTO.

47 Ibid., para. 7.130 .

48 Ibid., paras. 7.133-7.134. 
In other words, where the PTA leads to the economic situation necessitating a safeguard, the WTO member should be expected to roll back benefits granted to its PTA partner(s) rather than those granted across the board to all WTO members.

The Panel clarified that 'Article XIX:1(a) of the GATT 1994 allows a safeguard measure to be applied only if, as a result of obligations incurred under the GATT 1994, an importing member is confronted with an unforeseen development that it did not foresee or expect when it incurred these obligations. ${ }^{39}$ By nature, obligations incurred under a PTA, such as CAFTA-DR or the CA-DR FTA are not 'obligations incurred under the GATT 1994'. Thus, the Panel rejected the Dominican Republic's argument that its PTA could serve as an unforeseen development.

Certainly, had the Panel accepted one or both arguments as fulfilling the unforeseen development requirement, this would have opened the door to making it easier for WTO members to utilize safeguards. Without getting into the argument over whether such a move would be positive, we simply note that if this is the desired outcome, then the proper way to do so is through a re-examination of the 'unforeseen development' requirement itself. Trying to pass off an event as unforeseen when it clearly was foreseeable is not the right approach, and the Panel was correct to reject it.

Consequently, the Panel's rulings in the Dominican Republic-Safeguard Measures disputes ensure that satisfaction of the unforeseen developments requirement remains as difficult as ever. These cases provide important additional legal clarification that two trade-impacting phenomena - the ever-popular trend of negotiating PTAs and the re-entry of China into the global economy - cannot serve as the basis for meeting this requirement. Whether the $\mathrm{AB}$ in the future will reexamine the requirement remains to be seen, but for now, the requirement persists as a difficult legal hurdle - and one that the Dominican Republic, like many prior defendants, failed to clear. ${ }^{50}$

\subsection{The parallelism principle: does it apply when WTO members exclude de minimis imports from certain developing countries?}

A third issue raised in the Dominican Republic-Safeguard Measures cases concerns the scope of the parallelism principle that had developed out of prior WTO case law on safeguards and PTAs. The earlier cases concerned instances where a WTO member sought to exclude imports of a PTA partner from a safeguard. The AB held that if a WTO member sought to do so, then it must also exclude imports from PTA partners as part of its overall investigation analysis into increased imports,

49 Ibid., para. 7.142 (emphasis in the original).

50 See, for example, Appellate Body Report, US-Lamb Safeguards, para. 75; Panel Report, Argentina-Definitive Safeguard Measure on Imports of Preserved Peach, WT/DS238/R, adopted 15 May 2003, para. 7.35; Appellate Body Report, US-Steel Safeguards, para. 323. 
injury, and causation. In other words, the parallelism principle requires symmetry 'between the scope of imports subject to the safeguards investigation and the scope of the imports subject to the application of the measure'. ${ }^{51}$ What falls under one must fall under the other (and vice versa).

The fact pattern in these disputes differs from the prior parallelism cases in that the Dominican Republic did not seek to exclude imports from its PTA partners. Rather, as described in Section 2 above, imports from PTA partners were one of the key reasons for its pursuance of safeguards in the first place. Hence, the Dominican Republic included imports from PTA partners in its investigation and also as part of the applicable scope. So far, as the traditional parallelism issue was concerned, the Dominican Republic's actions complied fully with prevailing WTO law.

However, the Dominican Republic did seek to exclude imports from four developing countries (Colombia, Indonesia, Mexico, and Panama) with de minimis levels of imports of the products under investigation, pursuant to Article 9.1 of the Agreement on Safeguards. As Article 9.1 is a binding legal obligation incumbent on all WTO members, the Dominican Republic's act to exclude developing countries with a de minimis level of imports was by no means novel or unique. Moreover, the Dominican Republic, like other WTO members before it, had included the four developing countries as part of its overall investigation analysis of increased imports, injury, and causation, even though such imports were excluded from the final safeguard. Such behaviour has gone unchallenged in prior safeguards notified by others to the WTO.

The four complainants, however, asserted that such behaviour was inconsistent with the parallelism principle. If such imports were to be excluded from the final safeguard, then they suggested that such imports should also be excluded from the various investigation analyses into increased imports, injury, and causation. In short, the complainants suggested that the parallelism principle, developed to address the exclusion of imports from PTA partners, should also apply to the exclusion of imports from developing countries with a de minimis share. This dispute marks the first time that the WTO has been called upon to decide whether the parallelism principle extends beyond the PTA context to also include exclusion of certain developing countries pursuant to Article 9.1 of the Agreement on Safeguards.

The complainants, defendant, and third parties differed in their views on the scope of the parallelism principle. The complainants argued that the parallelism principle was one established by the $\mathrm{AB}$ as a 'general formula without exceptions' and therefore should apply 'irrespective of the reasons for which a [WTO] Member has decided to exclude certain imports from the application 
of the measure. ${ }^{52}$ The Dominican Republic, along with several third parties, ${ }^{53}$ however, asserted that the parallelism principle does not extend to exclusions made pursuant to Article 9.1 of the Agreement on Safeguards. They note that the parallelism principle arises, according to the $\mathrm{AB}$, because of the parallel language between Articles 2.1 and 2.2 of the Agreement on Safeguards. ${ }^{54}$ However, because Article 9.1 functions as an exception to Article 2.2 of the Agreement on Safeguards (but not Article 2.1), the Dominican Republic argued that Article 9.1 also acts accordingly as an exception to the parallelism principle. ${ }^{55}$

On this issue, the Panel sided with the Dominican Republic, highlighting the importance of Article 9.1 as a mandatory obligation that affects the scope of a WTO member's obligations under Article 2.2 of the Agreement on Safeguards. ${ }^{56}$ As a result, it ruled that the parallelism principle does not extend to instances where a WTO member demonstrates that its exclusion of certain developing countries is done in satisfaction of the requirements of Article 9.1 of the Agreement on Safeguards. ${ }^{57}$ Under such circumstances, the Panel declared that it 'does not consider it necessary [for a WTO member] to undertake a new analysis of the increase in imports, the injury, and causation'. ${ }^{58}$

In our view, the Panel's ruling on this question is correct. The question turns on whether the Agreement on Safeguards provides for a meaningful difference in its treatment of de minimis imports from developing countries and imports excluded from other sources (e.g., PTA partners). If not, then consistency principles would suggest that we ought to treat these excluded imports in a similar manner-i.e., apply the parallelism principle to both circumstances. But if a meaningful difference does exist, then this raises legitimate questions as to whether we ought to treat the parallelism principle as a general rule, as the complainants would have us do.

An examination of the text of the Agreement on Safeguards reveals important and meaningful differences. The $\mathrm{AB}$ developed the parallelism principle as a means of addressing a context on which the Agreement on Safeguards is silent. Nothing in the Agreement speaks to how WTO members are to consider imports from PTA partners in the context of the safeguards investigation. As a result, the AB

52 Panel Report, Dominican Republic-Safeguard Measures, para. 7.357 (citing Complainants' Second Written Submission, paras. 239 and 241; Complainants' Oral Statement at the First Panel Meeting, para. 116; and Complainants' Reply to Panel Question No. 156).

53 The United States, Turkey, and the European Union all issued statements before the Panel on this issue in support of the Dominican Republic's argument on this question. See ibid., paras. 7.362 and 7.3647.365. In contrast, Nicaragua issued a statement as a third party in favour of the complainants' argument. See ibid., para. 7.364.

54 See Appellate Body Report, US-Steel Safeguards, para. 439.

55 See Panel Report, Dominican Republic-Safeguard Measures, para. 7.360; see also ibid., para. 7.362 (noting similar argument made by the United States to the Panel on this issue).

56 Ibid., paras. 7.375-7.383.

57 Ibid., para. 7.385.

58 Ibid. 
considered it necessary to create rules in order to ensure that WTO members behave consistently in their treatment of imports with respect to their safeguards investigation and its subsequent application of safeguard measures (i.e., their obligations under Articles 2.1 and 2.2 of the Agreement on Safeguards). ${ }^{59}$ In contrast, the Agreement on Safeguards is not silent about the exclusion of imports from developing countries accounting for less than $3 \%$ of the total share of imports. Instead, the Agreement expressly contemplates this type of exclusion in Article 9.1 of the Agreement on Safeguards. The provision makes clear that exclusion of de minimis imports from developing countries functions as an exception to Article 2.2, as the Panel highlighted in its decision. ${ }^{60}$ By extension, Article 9.1 therefore also functions as an exception to general principles applicable to Article 2.2 such as parallelism. Had the negotiators not intended for this to be the case, they could have easily stipulated as much in the text of the provision, thereby limiting the scope of the exception. This difference in context is important, for it suggests that the parallelism principle is inapposite to a context clearly contemplated and addressed in the treaty text itself.

Another important difference concerns the nature of the decision at hand. The decision as to whether to exclude imports from a PTA partner from a safeguard investigation and from the application of a safeguard is a discretionary one, left up to each WTO member. Some, such as the US in US-Wheat Gluten, may decide to do so; others, such as the Dominican Republic in these disputes, may decide not to exclude. The parallelism principle developed as a means to ensure that WTO members, when making these discretionary decisions, do not behave inconsistently in a manner that serves protectionist interests. By contrast, the decision at issue here is not discretionary. WTO members are required to exclude de minimis imports from developing countries, pursuant to their obligations under Article 9.1 of the Agreement on Safeguards. Yet, although their exclusion is required in terms of the application of safeguard, the text is silent about whether this exclusion is also required for the safeguards investigation. Again, had negotiators wanted to address this issue expressly in the text, they could have done so. The fact that they did not suggests that they intended to leave flexibility for WTO members to include these imports during the investigation, if they so desired.

As a result, the Panel was correct to reject the complainants' argument that the parallelism principle should extend to the treatment of excluded imports made pursuant to Article 9.1 of the Agreement on Safeguards. This type of exclusion falls into an entirely different category than those contemplated by the $\mathrm{AB}$ when developing the parallelism principle. The Panel's ruling provides important

59 Note that Article 2.1 of the Agreement on Safeguards addresses the requirements that the WTO member must satisfy as part of its investigation of a safeguards petition, including an analysis of increased imports, injury, and causation. Article 2.2 of the Agreement on Safeguards addresses the application of safeguard measures.

60 See Panel Report, Dominican Republic-Safeguard Measures, para. 7.375. 
clarification that such exclusions are exempt from the parallelism principle otherwise applicable to safeguards.

\subsection{Selective exclusion of de minimis imports from developing countries}

Besides the question of parallelism, the Dominican Republic-Safeguard Measures cases raised yet another issue concerning interpretation of Article 9.1 of the Agreement on Safeguards. The provision states:

Safeguard measures shall not be applied against a product originating in a developing country Member as long as its share of imports of the product concerned in the importing Member does not exceed 3 per cent, provided that developing country Members with less than 3 per cent import share collectively account for no more than 9 per cent of total imports of the product concerned.

The Panel was called upon to clarify what discretion, if any, a WTO member has in determining which developing countries' imports are to be exempt from a safeguard measure on the basis of Article 9.1 of the Agreement on Safeguards. Only one previous WTO case, US-Line Pipe, has addressed the scope of a WTO member's obligations under Article 9.1. The AB, in US-Line Pipe, held that WTO members are not obliged to provide a list of developing countries expressly excluded from the measure. ${ }^{61}$ However, that case did not address the obligations of a WTO member that chooses to draw up such a list.

Recall that the Dominican Republic specifically chose to exclude four developing countries (Colombia, Indonesia, Mexico, and Panama) from the safeguard because their import shares qualified as de minimis according to Article 9.1. However, the Dominican Republic's list did not include a fifth developing country, Thailand, whose import share also fell below the de minimis level. The technical reports prepared by the government showed that imports of the concerned products from Thailand amounted to $0.32 \%$ of the Dominican Republic's total imports over the period of investigation (2006-2009) - well below the 3\% threshold established in Article 9.1.62 In addition, inclusion of the Thai imports would not have caused the Dominican Republic to exceed the 9\% collective threshold. Even if Thai imports were added to those of the other four developing countries, their collective share of total imports would amount to a mere $1.53 \% .{ }^{63}$ By not exempting imports from Thailand even though it was similarly situated as the other four developing countries, the complainants asserted that the Dominican Republic violated Article 9.1 of the Agreement on Safeguards.

Interestingly, it was not the negatively affected party, Thailand, but rather the four Central American complainants that raised the question of whether

61 Appellate Body Report, US-Line Pipe, para. 127.

62 Panel Report, Dominican Republic-Safeguard Measures, para. 7.398.

63 Ibid. 
the Dominican Republic's selective exclusion was proper. ${ }^{64}$ This suggests that the Central American producers did not view Thai producers as serious competitors; otherwise, they would not have been so keen to exempt Thai products from the safeguard measures which their own products faced. Instead, the four Central American governments likely foresaw longer-term benefit from having this legal question clarified. Even if their producers did not benefit in this particular instance, a ruling on this issue might benefit another export industry in the future facing a safeguard in a different context.

The Dominican Republic sought to defend its exclusion of Thailand from the exemption required by Article 9.1 on the grounds that there were no imports from Thailand of the investigated products in the last full year prior to when the safeguard went into effect (2009). ${ }^{65}$ The logical thrust of its argument was that the text of Article 9.1 only requires the non-application of safeguard measures against actual de minimis imports from developing countries. If no imports actually come from a given developing country, then there is no need to exempt that country under Article 9.1. What matters, according to the Dominican Republic, is whether actual imports exist at the time of the safeguard's imposition, and not whether they had existed during the period of investigation. On this basis, the Dominican Republic did not think it necessary to declare Thailand to be among the developing countries whose imports were exempt pursuant to Article 9.1. Moreover, the Dominican Republic explained, if imports from Thailand resumed and Thailand then requested an exemption, it would have been prepared to grant it. ${ }^{66}$

The Panel sidestepped the question of whether Article 9.1 of the Agreement on Safeguards requires that a WTO member exclude developing countries which had been the source of de minimis levels of imports during the period of investigation, even if they are no longer the source of any imports at the time that the safeguard is imposed. Instead of providing an answer, the Panel simply acknowledged that ' $[\mathrm{t}]$ here is a degree of flexibility regarding the way in which each Member may comply with Article 9.1'.67 This was an express recognition of the AB's pronouncements in US-Line Pipe that 'Article 9.1 does not indicate how a Member must comply with this obligation.' 68

While a WTO member may have considerable flexibility in how it wishes to operationalize Article 9.1, the Panel's view is that once a WTO member decides to proceed down a certain path, it must act consistently in its treatment of developing countries. In this instance, what rendered the Dominican Republic's actions problematic in the eyes of the Panel was the fact that the Dominican Republic behaved inconsistently with respect to countries that fell into the category of having

64 In fact, Thailand did not even participate as a third party in the disputes.

65 Panel Report, Dominican Republic-Safeguard Measures, para. 7.399.

66 Ibid.

67 Ibid., para. 7.396.

68 Appellate Body Report, US-Line Pipe, para. 127. 
(a) de minimis levels of imports of the affected products during the period of investigation, but (b) no imports at the time of the safeguard's implementation. In 2009, Colombia, Indonesia, Panama, and Thailand all fell into this category. Yet, of these four countries, only Thailand was not expressly included in the list of countries whose imports were exempt from the safeguard. The Panel noted that the Dominican Republic had failed to provide a convincing explanation for why it chose to treat Thailand differently. ${ }^{69}$ As a result, the Panel determined that the Dominican Republic 'did not take all reasonable measures available to it to exclude from application of the measures contested all developing countries which export less than the de minimis levels indicated in Article 9.1 of the Agreement on Safeguards, and [consequently] acted inconsistently with its obligations under Article 9.1 of the Agreement on Safeguards' ${ }^{70}$

The Panel essentially read into Article 9.1 a requirement that WTO members not discriminate between similarly situated developing countries when exempting them from the coverage of a safeguard measure. Although this non-discrimination principle is non-existent in the text of the provision itself, we believe that the Panel's interpretation is correct. Within the Agreement on Safeguards, Article 9.1 functions as a provision mandating special and differential treatment of developing countries. In EC-Tariff Preferences, the $\mathrm{AB}$ made clear that in the context of providing special and differential treatment, WTO members should not discriminate between similarly situated developing countries. ${ }^{71}$ Therefore, if two developing countries both qualify under the de minimis thresholds of Article 9.1 and a WTO member only grants one an exemption from a safeguard, it must distinguish between the two so as to justify its differentiation. The Dominican Republic's failure to do so, especially when Thailand's situation appears identical to that of three of the four exempt developing countries, is fatal to its defence.

At the same time, the Panel avoided addressing the question of whether the Dominican Republic must have included Thailand in the list of countries exempt pursuant to Article 9.1 of the Agreement on Safeguards. Could it instead have avoided naming all four similarly situated countries (Colombia, Indonesia, Panama, as well as Thailand) on its list? In other words, would limiting one's list of exempt countries to only those exporting at the time of the safeguard measure's implementation (i.e., listing only Mexico) be legal? The Panel deferred, choosing instead to leave this question for a future case. It suggested that regardless of the answer to this outstanding question, the Dominican Republic's actions were inconsistent and discriminatory in that it chose to exempt only some-as opposed

69 Panel Report, Dominican Republic-Safeguard Measures, paras. 7.400-7.401.

70 Ibid., para. 7.402 (emphasis in the original).

71 Appellate Body Report, European Communities - Conditions for Granting of Tariff Preferences to Developing Countries, WT/DS246/AB/R, adopted 20 April 2004, para. 173. 
to none or all - of the countries that had stopped exporting. Given the facts of the case, this exercise of judicial restraint appears prudent.

Therefore, while the Panel refused to extend the principle of parallelism to Article 9.1 of the Agreement on Safeguards, it had no such qualms about the principle of non-discrimination of similarly situated developing countries. Given the centrality of this principle to the trade regime, and the fact that the $\mathrm{AB}$ in EC-Tariff Preferences has specifically emphasized it in the context of special and differential treatment, the Panel's ruling on this issue provides valuable clarification about how WTO members are to operationalize their obligation under Article 9.1. When it comes to providing exemptions to safeguard measures, WTO members may not selectively differentiate without providing a convincing explanation of why this is necessary.

\section{Key implications}

The Panel decision offers important legal clarification for governments seeking to implement safeguards in conformity with their WTO treaty obligations. Beyond these jurisprudential issues, however, the Dominican Republic-Safeguard Measures cases may have important implications for how the proliferation of PTAs is impacting a country's calculus of how best to implement a safeguard measure in light of WTO litigation. These disputes suggest that the intersection between PTAs, safeguards, and WTO litigation is much more complex than the simple narrative that PTAs lower tariffs which necessitate safeguards that in turn trigger WTO litigation. In this final section, we turn to examine the broader implications.

\subsection{Policy constraints emergent from preferential trade agreements}

Despite all the excitement of potential upside gains from preferential market access to key export markets, PTAs come with their own set of perils. These potential downside perils, we suggest, are not simply economic (e.g., risks from PTA tariff concessions). Instead, what the Dominican Republic-Safeguard Measures cases make clear is the fact that they may also take on a legal form, such as when a PTA limits its member countries' policy options for adjusting to trade shocks. The size and impact of this downside peril is one which is determined by countries themselves during the course of their PTA negotiations.

To make this point more concrete, consider the following question: What if the Dominican Republic had not signed a PTA with the Central American countries? In exchange for not gaining preferential access to its markets, the Dominican Republic could have responded as many other WTO members normally do-by simply raising their applied tariff rate in a non-discriminatory manner to the level at (or below) its bound tariff rate. In other words, without a PTA, the Dominican Republic could have very easily implemented its desired policy of raising the applied MFN tariff to the $38 \%$ ad valorem rate. 
One difference between this hypothetical move and the one actually implemented by the Dominican Republic is the scope of countries subject to the higher applied tariff. For this move to pass WTO muster, the Dominican Republic would have had to apply it to all of its trading partners; it could not have exempted the four developing country de minimis suppliers. There is no indication that this exemption was of much policy importance to the government; it appears to have been enacted simply to satisfy the requirements of Article 9.1 of the Agreement on Safeguards. As a result, the hypothetical move is likely to have been the first-best policy alternative in the government's eyes, but one foreclosed by the PTA.

Global safeguards emerge as a second-best alternative policy option. From the domestic producers' perspective, they remain inferior to the first-best alternative of simply raising applied MFN tariff rates, as a country in the Dominican Republic's situation, but for the PTA, would be wont to do because, inter alia, they require a time-consuming and resource-intensive investigation; they are time-limited; and they require the exemption of imports from certain developing countries. ${ }^{72}$ Most importantly, as this case demonstrates and as others have previously suggested, WTO safeguards are difficult to implement because of the 'unforeseen development' requirement. In particular, if trade liberalization resulting from the PTA is the economic shock necessitating a safeguard but a PTA negotiated subsequent to the last multilateral tariff negotiation cannot qualify as unforeseen for purposes of a WTO safeguard, then the second-best policy alternative may also be foreclosed as a result of the PTA.

What options are left for a country faced with a situation similar to that of the Dominican Republic? One option is to implement protection through an alternative temporary trade barrier policy instrument, such as antidumping or countervailing duties. But this alternative too may be foreclosed, depending on the facts of the matter at hand. The imposition of an antidumping duty requires that the domestic industry demonstrate that the product is being imported below its 'normal value', which may not always be possible to prove, especially when the import is from a PTA partner considered to be a market economy. The imposition of a countervailing duty requires that the foreign producer be subsidized by its government with certain unfair conditions; again, this is difficult to demonstrate as many foreign producers, such as the ones in this case, do not benefit from subsidies. This alternative too may be non-viable because of an inability to meet either of these conditions.

Another alternative is to turn to an extraordinary safeguard, meaning one which is not taken under the auspices of GATT Article XIX or the Agreement on Safeguards. An example is the China-specific transitional safeguard, spelled forth

72 On the other hand, some of these characteristics are what make this policy attractive to governments so as to allow some flexibility but to prevent the over-use (and abuse) of requests for new import protection and to ensure that new protection is short-lived when it does arise. 
in China's Protocol of Accession. ${ }^{73}$ Given that a significant portion of the increase in the imports of the affected products was from China, this alternative is of relevance in this dispute (although we recognize that it would not necessarily always be the case in other PTA-related safeguards disputes).

The other relevant alternative is the safeguard measure permitted under the PTA itself. PTA-specific safeguards fall outside of the scope of the WTO covered agreements and apply only as an escape clause for commitments arising out of the PTA. The utility and applicability of such a safeguard is context-specific, but it bears noting that these elements are well within the control of the country at the negotiating table. Therefore, a country ought to pay careful attention to the terms of the provisions governing safeguards during the course of the PTA negotiations. Such terms may well further tie the hands of the PTA-enacting country, in terms of its ability to trigger an escape clause when faced with an import shock following the PTA.

Although the terms of the PTA-specific safeguard do not feature directly in this dispute, they are worth examining because the PTA-specific safeguard represents an alternative to the WTO safeguard enacted by the Dominican Republic and found to be illegal by the Panel. What did CAFTA-DR itself allow in terms of a safeguard? And why did the Dominican Republic reject simply using this safeguard rather than pursuing a WTO safeguard then deemed illegal by the Panel?

The provisions governing the use of a safeguard to obtain a temporary reprieve from a CAFTA-DR commitment are spelled out in Chapter 8 of the agreement which establishes CAFTA-DR-specific rules on trade remedies. Article 8.1 states:

1. A Party may apply a measure described in paragraph 2, during the transition period only, ${ }^{74}$ if as a result of the reduction or elimination of a duty pursuant to this Agreement, an originating good is being imported into the Party's territory in such increased quantities, in absolute terms or relative to domestic production, and under such conditions as to constitute a substantial cause of serious injury, or threat thereof, to a domestic industry producing a like or directly competitive good.

2. If the conditions in paragraph 1 are met, a Party may to the extent necessary to prevent or remedy serious injury, or threat thereof, and facilitate adjustment:

(a) suspend the further reduction of any rate of duty provided for under this Agreement on the good; or

(b) increase the rate of duty on the good to a level not to exceed the lesser of

(i) the most-favored-nation (MFN) applied rate of duty in effect at the time the measure is applied, and

73 China Accession Protocol, paras. 16.1-16.9.

74 The meaning of the term 'transition period' is defined in Art. 8.7 of CAFTA-DR as 'the ten-year period beginning on the date of the entry into force of this Agreement' except for those goods whose period for tariff elimination extends beyond ten years. 
(ii) the MFN applied rate of duty in effect on the day immediately preceding the date of entry into force of this Agreement.

Articles 8.2 through 8.5 elaborate upon further requirements pertaining to the timing and gradual reduction, notification, and compensation. Finally, Article 8.6(3) makes clear that CAFTA-DR members are allowed to maintain WTO global safeguards pursuant to GATT Article XIX and the Agreement on Safeguards, but that CAFTA-DR countries must choose between a WTO safeguard and a CAFTA-DR safeguard; they cannot implement both simultaneously.

An examination of these provisions of CAFTA-DR reveals two interesting points: First, unlike a WTO global safeguard, nothing within Chapter 8 requires the existence of an 'unforeseen development'. Therefore, unless an arbitral panel reads this requirement into the language, it appears that one of the barriers to imposing a WTO safeguard disappears in the context of a CAFTA-DR-specific safeguard. However, this benefit is undercut by a second point worth noting. Through Article 8.2(b), CAFTA-DR places an upper-bound limit on the tariff rate to be applied as part of a CAFTA-DR safeguard. The provision makes clear that a CAFTA-DR member may not apply a safeguard tariff rate that is higher than the MFN applied tariff rate in force on the day immediately prior to CAFTA-DR's entry into force. Nor may it impose a safeguard tariff rate that is higher than the MFN applied tariff rate in force on the day on which the CAFTA-DR-specific safeguard is applied. In this circumstance, the MFN applied rate remained unchanged (at 20\% for polypropylene bags and 14\% for tubular fabric) between the two dates. Therefore, were the Dominican Republic to enact a CAFTA-DR safeguard, it could only raise the applied tariff on polypropylene bags from the CAFTA countries to these applied MFN rates, which are significantly lower than the tariff rate of $38 \%$ imposed by the government or of $73 \%$, as sought by domestic industry in the original petition.

In this particular case, the presence of Article 8.2(b) of CAFTA-DR therefore renders the PTA-specific safeguard to be a less attractive alternative to the domestic industry than the WTO safeguard. Compared to the three other alternatives discussed above, the PTA-specific safeguard is a fourth-best alternative, albeit possibly the only one that can be implemented legally. Yet, what we wish to highlight is that it need not necessarily always be the case that the PTA-specific safeguard is less attractive than the WTO safeguard. Instead, it turns on the wording of the safeguards-related provision in the PTA itself.

To demonstrate this point, consider if Article 8.2(b) had been drafted instead with only subprovision (i) but not subprovision (ii). Were this to be the case, then the PTA would simply mandate that when imposing a PTA-specific safeguard, a country could not apply a tariff rate higher than the existing MFN applied rate. The further requirement preventing the safeguard rate from exceeding the applied rate at the time of the PTA's entry into force would be eliminated. Under this hypothetical scenario, so long as the Dominican Republic raised the applied MFN 
tariff rate to $38 \%$ ad valorem first (which it could have easily done), then it could subsequently raise the CAFTA-DR-specific safeguard tariff also to the level of $38 \%$.

Drafting language in PTA provisions matters, as it can significantly constrain a country's ability to use safeguards. Put differently, had the Dominican Republic had the foresight to push back against inclusion of subprovision (ii) in Article 8.2(b) during the course of the CAFTA-DR negotiations, then it could have averted this dispute altogether. On a theoretical level, the Dominican Republic could have easily made a colourable argument for such a position. After all, the purpose of a PTA safeguard is to provide an escape clause whereby a PTA member is able to undo the preferential treatment applied to PTA partners. Subprovision (i) helps to effectuate this purpose, whereas subprovision (ii) undermines it.

Had the Dominican Republic pushed for this position and prevailed, ${ }^{75}$ then its policy options would be quite different. It could have raised the applied MFN rate and then imposed a CAFTA-DR safeguard to get to the desired result of a $38 \%$ ad valorem tariff on the products. Instead, the Dominican Republic settled for a safeguards provision that allowed it only an incomplete escape clause. The CAFTADR safeguard does not necessarily allow one to escape the grant of preferential treatment altogether; it only does so in situations where the country has not chosen to raise the applied MFN tariff rate since the treaty's entry into force. This acceptance of the limitations of Article 8.2(b)(ii), in turn, sets the Dominican Republic down the path of pursuing the illegal WTO safeguard instead.

PTAs, therefore, can constrain the legal policy options of the treaty partners in both expected and unexpected ways. In this case, a single subprovision within a PTA served to seriously impair the ability of a country to use safeguards as an escape clause to reinstate applied MFN tariffs at a level squarely in line with its WTO obligations. Whether this implication was clear to Dominican negotiators or not at the time they agreed to CAFTA-DR is unknown. Regardless, this set of cases should serve as forewarning to those countries currently negotiating PTAs to pay careful attention to the language of the trade remedies provisions. Otherwise, they too risk signing a PTA that imperils the scope of their ability to implement temporary trade barriers which would allow them to mitigate the shocks of PTA-induced trade liberalization.

\subsection{Steering jurisdiction through policy choice}

In an attempt to prevent the Panel from deciding on the case, the Dominican Republic raised a preliminary objection challenging whether the WTO had

75 We note, however, that even if Dominican negotiators had pushed for this position, it is unlikely that they would have prevailed. As discussed in Section 2, because of the late stage at which the Dominican Republic joined the CAFTA negotiations, the Dominican Republic was expected to integrate into the framework already agreed upon between the United States and the Central American parties to the agreement. At that stage, Article 8.2(b)(ii) was already part of the framework. 
jurisdiction to address a claim raised by a partner to a PTA and asking the Panel to decline jurisdiction. In past cases, the WTO has clarified that the WTO is free to entertain claims, even if they arise in connection with a PTA, so long as the claims pertain to a WTO covered agreement. That appears to be the case here as well. However, the Dominican Republic attempted to muddle the issue by arguing that the claims were ones related to CAFTA-DR rather than to a WTO covered agreement. It asserted that the complainants' claim concerned the Dominican Republic's application of a tariff in excess of the $0 \%$ ad valorem rate to be provided in PTAs signed between the parties. ${ }^{76}$

The complainants quickly asserted that the Dominican Republic's claims were groundless. They noted that their claims were exclusively related to the WTO covered agreements - specifically, the GATT and the Agreement on Safeguardsand they had not requested for the Panel to rule on any infringement of CAFTADR. ${ }^{77}$ In light of an agreement between the parties, the Panel chose not to comment further and proceeded with exercising its jurisdiction. ${ }^{78}$

While the jurisdictional issue was resolved between the parties, this dispute does raise interesting questions about how a country intent on escaping a PTA obligation can steer the forum under which it will need to defend its trade action towards or away from WTO dispute settlement. This decision will depend on whether the country finds the WTO to be a more or less favourable forum than the dispute settlement alternative contained within the PTA.

As noted in the previous subsection, the Dominican Republic had several alternative policy options that it could have pursued. Doing so would have allowed the Dominican Republic to escape WTO jurisdiction and instead consign litigation to a dispute settlement proceeding of the PTA (i.e., CAFTA-DR Chapter 20 proceeding).

First, one option for the Dominican Republic was simply raising its applied tariff rate on both products to $38 \%$ ad valorem across the board. As this falls below its bound tariff rate of $40 \%$ on both products, such a move would not have run afoul of the Dominican Republic's WTO commitments on tariffs. Moreover, by raising it across the board to include imports from all countries, the Dominican Republic would avoid any MFN violation. Finally, by executing it as simply a rise in the applied tariff rate rather than as a safeguard, the Dominican Republic avoids any obligations under GATT Article XIX and the Agreement on Safeguards. The only violations in this scenario are with respect to the PTA and not the WTO. Thus, the Central American countries would be forced to pursue their claims via CAFTA-DR, rather than WTO, dispute settlement.

\footnotetext{
76 Panel Report, Dominican Republic-Safeguard Measures, para. 7.92.

77 Ibid., para. 7.93

78 Ibid., paras. 7.97-7.98.
} 
A second potential option for the Dominican Republic was to enact two extraordinary safeguards instead of a WTO global safeguard. This would mean imposing (1) a China-specific transitional safeguard under the WTO, and (2) a CAFTA-DR-specific safeguard. Let us consider each of these extraordinary safeguards in turn.

Enactment of a China-specific safeguard requires that a WTO member meet certain conditions set forth in paragraph 16 of China's Protocol of Accession. ${ }^{79}$ A quick glance at the facts of this case suggests that these conditions could have been easily met. Figure 2 a shows a rapid spike in imports from China of the affected products during 2005-2008, leading to a market disruption. ${ }^{80}$ So long as the Dominican Republic took the requisite steps in its investigation, it could have set the China-specific safeguard tariff rate at $38 \%$ ad valorem on both products. This would accomplish the objective of raising tariffs on imports from China without violating any of the Dominican Republic's treaty commitments. No WTO litigation would arise from the first of the two extraordinary safeguards.

Rather than relying on a WTO global safeguard to raise tariffs on imports from Central America, the Dominican Republic could have employed a CAFTA-DRspecific safeguard. As noted earlier, Article 8.2(b) of CAFTA-DR prevents the Dominican Republic from applying a CAFTA-DR-specific safeguard rate above the applied MFN tariff rate in place at the time of the extraordinary safeguard's imposition or in effect on the day prior to CAFTA-DR's entry into effect. Therefore, in order to comply with its treaty obligations under CAFTA-DR, the Dominican Republic could not impose a CAFTA-DR-specific safeguard above $20 \%$ for polypropylene bags and $14 \%$ for tubular fabric. However, the Dominican Republic could have chosen to ignore this limitation and gone ahead with setting the tariff rate at $38 \%$ anyway. Doing so would result in a breach of CAFTA-DR Article 8.2(b)(ii). But because the violation is of a CAFTA-DR-specific obligation rather than a WTO obligation, the Central American countries' only recourse would be to pursue their claim via CAFTA-DR dispute settlement. No WTO litigation would arise out of imposition of this second extraordinary safeguard either.

In other words, had the Dominican Republic really wanted to escape WTO jurisdiction, it had two alternative policy options available that would allow it to do so. Granted, these two alternative options do not wind up with a policy outcome that is exactly identical to that which was actually implemented, but they do come pretty close to achieving the same objective. Assuming that the actual policy

79 The special country-specific safeguard may be invoked in 'cases where products of Chinese origin are being imported into the territory of any WTO Member in such increased quantities or under such conditions so as to cause or threaten to cause market disruptions to the domestic producers of like or directly competitive products'.

80 The volume of Chinese imports of polypropylene bags and tubular fabric declined in 2009, but this decline is in conjunction with a worldwide decline in trade during the Great Recession. 
outcome is viewed as optimal, the first alternative (i.e., raising applied MFN tariffs across-the-board) suffers from being over-inclusive because the breadth of countries affected by the higher tariff rate expands to include the four developing countries that were excluded from the WTO safeguard (i.e., Colombia, Indonesia, Mexico, and Panama). By contrast, the second alternative is under-inclusive because the number of affected countries contracts, as countries besides China that are not parties to CAFTA-DR (e.g., Thailand) are not covered. Nevertheless, given that imports from all of these countries represent such a small percentage (as shown in Figure 3), the cost of these policy outcome deviations and their accompanying trade diversionary effects are not likely to be significant. Our point is that a country seeking to escape a PTA obligation, through its choice of viable policy alternatives, can steer the dispute away from WTO dispute settlement rather than providing its PTA partner with a choice of forum.

Why did the Dominican Republic not do so? In this specific instance, dispute settlement provisions in CAFTA-DR are fairly robust: Chapter 20 of CAFTA-DR provides for an ad hoc three-person arbitral panel to adjudicate disputes, with each party to appoint a panellist and the chair to be chosen through mutual agreement or by lot. ${ }^{81}$ Furthermore, Chapter 20 also provides for the suspension of benefits in the event that a party does not alter its policy to conform to the ruling, pay compensation, or reach a mutually agreed solution. Given the similarities between CAFTA-DR and WTO dispute settlement, the Dominican Republic may not have had a strong preference between defending its measures before a WTO panel as opposed to a CAFTA-DR arbitral panel.

Yet, this will not always be the case. Many PTAs do not contain dispute settlement provisions that are as robust as Chapter 20 of CAFTA-DR. In such instances, it may be preferable to implement a policy choice that steers litigation towards dispute settlement under the PTA. Furthermore, defending a safeguard under the PTA may be preferable for many countries because of the 'unforeseen development' requirement in WTO jurisprudence. The PTA may well lack the 'unforeseen development' requirement altogether or a PTA arbitral panel may interpret it in a less stringent manner than the WTO has. Even if neither holds true, the reference-point timing shifts, possibly making it easier to satisfy the requirement.

In this particular dispute, we find it interesting that the Dominican Republic did not implement its policy through one of these other alternatives. Had it done so, it could have avoided defending its measure before the WTO and instead invited the Central American countries to test the Chapter 20 dispute settlement proceedings of CAFTA-DR. Other countries, looking at these disputes, should draw the lesson

81 Dominican Republic - Central America Free Trade Agreement, signed 5 August 2004, entered into force 1 March 2007 (for Dominican Republic), Art. 20.9. For an account of the Chapter 20 dispute settlement mechanism in CAFTA-DR, see Gantz (2007: 390-408). 
that when it comes to deciding how best to escape a PTA obligation, one ought to pay careful attention to the jurisdictional implications that will arise from one's choice of available policy options.

\subsection{The value of safeguards-related litigation in light of the remedy gap}

Finally, it is worth asking the question of what exactly did the complainants gain from their WTO litigation efforts. Presumably, the four complainants were motivated to bring their case to the WTO due to pressure from domestic producers that claimed they were being unfairly subject to safeguard measures that denied them the benefits expected out of CAFTA-DR and which violated the WTO agreements. But from an economic standpoint, there was little actual gain. Interestingly, the Dominican Republic rescinded its illegal safeguard measures on 21 April 2012 - the same day as that on which they were due to expire anyway.

In other words, although the applied safeguard measures were deemed illegal, the Dominican Republic succeeded in maintaining them for the entire duration of the original application. During this period, as Figure 3 shows, imports of polypropylene bags and tubular fabric from the affected countries dropped precipitously. Yet, due to the lack of retroactive remedies within the WTO system (i.e., the so-called remedy gap), ${ }^{82}$ the affected producers received no economic remedy from their suffering of an injustice. The WTO cases, on a very practical level, did not produce any meaningful difference for producers from the four Central American complainants of the products subject to the safeguard measures.

So why would the complainants bother to bring a case? Here we consider a number of likely contributing explanations. ${ }^{83}$

One possibility is that the four Central American countries found value simply in the establishment of favourable case law so as to stave off similar safeguards in the future. Furthermore, they may have wished to signal to trading partners the seriousness with which they were going to hold each other accountable to their trade liberalization commitments, especially with respect to a relatively new PTA, so as to prevent backsliding behaviour. ${ }^{84}$

A second contributing explanation is that, while the dispute may not have prevented the safeguard from remaining in place for its full duration, at least it

82 The decision to impose prospective remedies is the practice in the overwhelming majority of WTO cases, but this is not mandated in the Dispute Settlement Understanding and there is an isolated outlier case. See Mavroidis and Wu (2013: 1045). For a more complete discussion of the WTO remedy gap and its implications, see Brewster (2011).

83 Note that they are not mutually exclusive.

84 Bown and Hoekman (2008) note that more generally one of the serious problems associated with developing countries and trade agreements-especially for relatively poor countries-is that trading partners have been unwilling to bring forward dispute settlement challenges. They show how the failure to enforce through dispute settlement becomes complicit in condoning backsliding behaviour resulting in the unwinding of such agreements. 
helped ensure the safeguard was only in place for the originally intended period. There are a number of recent instances in which countries have chosen to extend safeguard measures for a second four-year period instead of removing the measure after its initial three- or four-year period has expired. ${ }^{85}$

A third possibility is that the countries simply wanted to build their capacity for trade-related litigation. For example, the case represents the first time that El Salvador has participated in a WTO dispute as a complainant. Because the countries used the subsidized legal assistance provided by the Advisory Centre on WTO Law (ACWL), it was a low-cost way to address a considerable concern for the trade interests of a particular industry (see again Figure 4), albeit one that involved a relatively small amount of trade when viewed in aggregate terms. ${ }^{86}$

A fourth possibility is that the motivation for the cases was internally oriented. Had the governments not taken action at the WTO, they might expect to face pressure from other domestic industries for safeguard measures similar to that granted by the Dominican Republic. Hoping to avoid such a situation, they filed a case which produces a ruling that they can then hold out to domestic industries for a reason why they cannot pursue the requested action.

While there may be good reasons for countries to litigate, for the WTO itself, the disputes raise some worrying concerns about the efficacy of its dispute settlement proceedings. The Dominican Republic provides an example of how a WTO member can take advantage of a 'free pass' to enact illegal safeguard measures to benefit its domestic industry without fear of WTO retribution. ${ }^{87}$ Others may find it tempting to follow in the Dominican Republic's footsteps, even if they know that they will eventually lose the case, because of the policy's efficacy in stemming imports. Unless the WTO handles such cases in a much more expeditious manner and/or addresses its remedy gap, it is possible that these rulings will not have much of a deterrent effect.

\section{Concluding remarks}

At first glance, the Dominican Republic-Safeguard Measures cases appear to underscore two trends in WTO litigation. The first is the growing tendency of

85 See, for example, Communication from Thailand to the Committee on Safeguards, Notification under Article 12.1(b) of the Agreement on Safeguards on Finding Serious Injury or Threat Thereof Caused by Increased Imports, Notification Pursuant to Article 12.1(c) of the Agreement on Safeguards, Notification Pursuant to Article 9, Footnote 2, of the Agreement on Safeguards (Glass Block), G/SG/N/8/ THA/1/Suppl.6, G/SG/N/10/THA/1/Suppl.4, G/SG/N/11/THA/1/Suppl.5, 8 August 2013.

86 Busch et al. (2009) provide a discussion of legal capacity needs of developing countries in WTO dispute settlement. Bown and McCulloch (2010) describe the empirical evidence on the ACWL.

$87 \mathrm{Ahn}$ (2006) documents a number of other past instances where the end of the implementation period following a WTO dispute settlement proceeding coincides with or is only months earlier than the end date of the initial safeguard measure. 
smaller developing countries to resort to WTO dispute settlement to enforce their WTO treaty obligations. The second is the likelihood that with the growing proliferation of PTAs, WTO litigation carries implications for not only multilateral treaty obligations, but also for obligations made through bilateral and plurilateral treaties. Both are undoubtedly true. But we suggest that the Dominican RepublicSafeguard Measures cases offer broader lessons beyond simply highlighting emergent trends in WTO litigation.

First, analyses of PTAs have focused on tariffs, market access (for both goods and services), regulatory harmonization, and other non-tariff barriers. These cases, however, underline the importance of paying close attention to the trade remedy provisions of PTAs. As CAFTA-DR's Chapter 8 signifies, WTO + and/or WTO-X concessions on trade remedies made in a PTA may place added constraints on a country's future ability to exercise escape clause mechanisms to assist domestic industries hurt by increased foreign competition. Developing countries, in particular, ought to pay closer attention to whether signing up for such constraints is prudent in light of these potential perils, rather than simply agreeing to these concessions in exchange for lower preferential tariffs and increased market access.

Second, the interplay between PTAs and safeguards involves a broader terrain than simply tariff and market access concessions. Such concessions may result in domestic industries facing increased competition from imports that may trigger the imposition of safeguards as an escape mechanism. But it is also possible for the increased pressures to arise from other factors that pre-date the PTA or that are entirely unrelated to the PTA. Moreover, these pressures may arise in a period of relative macroeconomic stability. Under such circumstances, the influence of the PTAs in affecting the course of implementing a safeguard measure arises not only from the precise tariff or market access concessions, but also from the PTA-specific provisions on trade remedies.

Third, a country that seeks to assist a struggling domestic industry in the face of new import protection must recognize the complexities of using safeguards in light of the specific terms of its PTAs as they relate to PTA-specific safeguards, tariffs, and dispute settlement. Moreover, they ought to weigh the relative attractiveness of using a WTO global safeguard, as opposed to a PTA-specific safeguard, countryspecific safeguard, and/or simply raising applied tariffs to a level below that of the bound tariff commitment. As the Dominican Republic-Safeguard Measures disputes show, the terms of a PTA affect whether a particular policy measure may be challenged before a WTO panel, a PTA-specific arbitral panel, or both. Countries may wish to consider in which forum they would prefer to defend their policies against any potential litigation from trading partners before embarking on any policy concerning safeguards.

Fourth, the move away from multilateralism is giving rise to new and interesting jurisprudential questions on safeguards. It may once have seemed unimaginable that a WTO panel would be asked to rule on whether a policy 
measure can be considered a safeguard if it does not contravene a treaty obligation concerning bound tariffs, quota, or quantitative restriction. As these cases illustrate, the rise of PTAs changes this equation. By adopting a broad reading of safeguards and foreclosing the ability of a WTO member to argue that PTA concessions or China's WTO entry serve as an 'unforeseen development', the WTO Panel addressed a number of these new questions in the attempt to prevent the already much-maligned safeguards jurisprudence from further veering off course.

Finally, for developing countries specifically, the evolving safeguards jurisprudence carries both good and bad news. The Panel interpretation of Article 9.1 of the Agreement on Safeguards ensures that WTO members will not discriminate against similarly situated developing countries. This limits the possibility of selective exclusion of certain developing countries from a safeguards exemption, at least without justification. It remains to be seen what types of criteria will be considered a permissible means of differentiation, but at the very least, a clarification in favour of non-discrimination is heartening. On the other hand, applied MFN tariff increases rather than safeguards may sometimes be a preferable policy for certain countries to avoid WTO dispute settlement and steer litigation towards PTA arbitral panels. Greater employment of this policy would subject a broader range of imports from developing countries to higher tariffs, as imports from countries whose levels fall below the de minimis threshold of Article 9.1 would no longer be exempt.

Overall, these cases highlight a new reality so far as PTAs and safeguards are concerned. As PTAs proliferate, the complexities facing WTO members also increase. The past cases suggested that the key question was over how to treat PTA partners when investigating and applying a safeguard petition. But these recent disputes suggest that this is no longer the only important concern. Instead, WTO members with PTAs must pay close attention to additional issues such as the costs and benefits of employing safeguards versus other policy measures; which types of safeguards to deploy; and what types of additional WTO + or WTO-X limitations on safeguards they should or should not agree to adopt. In short, countries need to be aware that PTAs may carry not simply economic perils for particular domestic industries, but also possibly legal perils for governments seeking to implement policies so as to assist those industries.

\section{References}

Ahn, D. (2006), 'Restructuring the WTO Safeguard System', in M. Matsushita, D. Ahn, and T.-J. Chen (eds.), The WTO Trade Remedy System: East Asian Perspectives, London: Cameron May, pp. 11-31.

Auyezov, O. (2013), 'Ukraine Imposes New Tariffs on Car Imports, Risking EU Ire', Globe and Mail, 14 March.

Bagwell, K. and R. W. Staiger (1990), 'A Theory of Managed Trade', American Economic Review, 80: 779-795. 
Baldwin, R., S. Evenett, and P. Low (2009), 'Multilateralizing Non-Tariff RTA Commitments', in R. Baldwin and P. Low, Multilateralizing Regionalism: Challenges for the Global Trading System, Cambridge: Cambridge University Press, pp. 79-141.

Bown, C. P. (2011), 'Introduction', in C. P. Bown (ed.), The Great Recession and Import Protection: The Role of Temporary Trade Barriers, London: CEPR and World Bank, pp. 1-51.

_ (2013), Temporary Trade Barriers Database, World Bank, http://econ.worldbank.org/ttbd/ (accessed 15 August 2013).

- (2014), 'Trade Policy Flexibilities and Turkey: Tariffs, Antidumping, Safeguards, and WTO Dispute Settlement', The World Economy, 37: 193-213.

Bown, C. P. and M. A. Crowley (2013a), 'Self-Enforcing Trade Agreements: Evidence from Time-Varying Trade Policy', American Economic Review, 103(2): 1071-1090.

_ (2013b), 'Emerging Economies, Trade Policy, and Macroeconomic Shocks', World Bank Policy 1538 Research Working Paper No. 6315, January.

Bown, C. P. and B. M. Hoekman (2008), 'Developing Countries and Enforcement of Trade Agreements: Why Dispute Settlement Is Not Enough', Journal of World Trade, 42(1): 177-203.

Bown, C. P. and R. McCulloch (2003), 'Nondiscrimination and the WTO Agreement on Safeguards', World Trade Review, 2(3): 327-348.

- (2004), 'The WTO Agreement on Safeguards: An Empirical Analysis of Discriminatory Impact', in M. G. Plummer (ed.), Empirical Methods in International Trade: Essays in Honor of Mordechai Kreinin, Cheltenham: Edward Elgar, pp. 145-168.

- (2010), 'Developing Countries, Dispute Settlement, and the Advisory Centre on WTO Law', Journal of International Trade and Economic Development, 19(1): 33-63.

Bown, C. P. and T. J. Prusa (2011), 'US Antidumping: Much Ado about Zeroing', in W. J. Martin and A. Mattoo (eds.), Unfinished Business? The WTO's Doha Agenda, London: CEPR and World Bank, pp. 355-392.

Bown, C. P. and P. Tovar (2011), 'Trade Liberalization, Antidumping, and Safeguards: Evidence from India's Tariff Reform', Journal of Development Economics, 96(1): 115-125.

Brewster, R. (2011), 'The Remedy Gap: Institutional Design, Retaliation, and Trade Law Enforcement', George Washington Law Review, 80: 102-156.

Busch, M. L., E. Reinhardt, and G. Shaffer (2009), 'Does Legal Capacity Matter? A Survey of WTO Members', World Trade Review, 8(4): 559-577.

Crowley, M. (2010), 'Why Are Safeguards Needed in a Trade Agreement?', in K. W. Bagwell, G. A. Bermann, and P. C. Mavroidis (eds.), Law and Economics of Contingent Protection in International Trade, Cambridge: Cambridge University Press, pp. 379-400.

Finger, J. M. and J. J. Nogués (2006), Safeguards and Antidumping in Latin American Trade Liberalization: Fighting Fire with Fire, Washington, DC: World Bank.

Fischer, R. D. and T. J. Prusa (2003), 'WTO Exceptions as Insurance', Review of International Economics, 11: $745-757$.

Gantz, D. (2007), 'Settlement of Disputes under the Central America-Dominican Republic-United States Free Trade Agreement', Boston College International and Comparative Law Review, 80(2): 331-410.

Grossman, G. and A. Sykes (2006), 'United States - Definitive Safeguard Measures on Imports of Certain Steel Products', in H. Horn and P. Mavroidis (eds.), The WTO Case Law of 2003, Cambridge: Cambridge University Press, pp. 146-187.

Mavroidis, P. C. and M. Wu (2013), The Law of the World Trade Organization (WTO), 2nd edn, St Paul, MN: West.

Pauwelyn, J. (2004), 'The Puzzle of WTO Safeguards and Regional Trade Agreements', Journal of International Economic Law, 7: 109-142.

Prusa, T. J. (2011), 'Trade Remedy Provisions', in J. Chauffour and J. Maur (eds.), Preferential Trade Agreement Policies for Development, Washington, DC: World Bank, pp. 179-196.

Sykes, A. (2003), 'The Safeguards Mess: A Critique of Appellate Body Jurisprudence', World Trade Review, 2: 261-295. 
_ (2004), 'The Persistent Puzzle of Safeguards: Lessons from the Steel Dispute', Journal of International Economic Law, 7: 523-564.

Teh, R., T. J. Prusa and M. Budetta (2009), 'Trade Remedy Provisions in Regional Trade Agreements', in A. Estevadeordal, K. Suominen, and R. Teh (eds.), Regional Rules in the Global Trading System, Cambridge: Cambridge University Press, pp. 166-249.

Wauters, J. M. (2010), 'The Safeguards Agreement-An Overview', in K. W. Bagwell, G. A. Bermann, and P. C. Mavroidis (eds.), Law and Economics of Contingent Protection in International Trade, Cambridge: Cambridge University Press, pp. 334-366. 